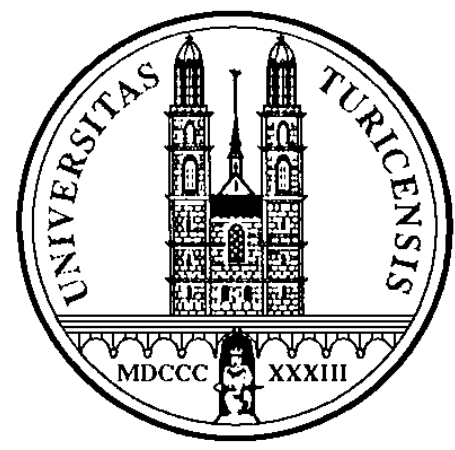

Institute for Empirical Research in Economics

University of Zurich

Working Paper Series

ISSN 1424-0459

Working Paper No. 44

Robustness and Real Consequences of

Nominal Wage Rigidity

Ernst Fehr and Lorenz Goette

March 2003 


\title{
ROBUSTNESS AND REAL CONSEQUENCES OF NOMINAL WAGE RIGIDITY
}

\author{
Ernst Fehr and Lorenz Goette* \\ University of Zurich
}

December 2002

\begin{abstract}
Recent studies found evidence for nominal wage rigidity during periods of relatively high nominal GDP growth. It has been argued, however, that in an environment with low nominal GDP growth, when nominal wage cuts become customary, workers' opposition to nominal cuts would erode and, hence, firms would no longer hesitate to reduce nominal pay. If this argument is valid nominal wage rigidity is largely irrelevant because in a high-growth environment there is little need to cut nominal pay while in a low-growth environment the necessary cuts would occur.

To examine this argument we use data from Switzerland where nominal GDP growth has been very low for many years in the 1990s. We find that the rigidity of nominal wages is a robust phenomenon that does not vanish in a low growth environment. In addition, it constitutes a considerable obstacle to real wage adjustments. In the absence of downward nominal rigidity, real wages would indeed be quite responsive to unemployment. Moreover, the wage sweep-ups caused by nominal rigidity are strongly correlated with unemployment suggesting that downward rigidity of nominal wages indeed contributes to unemployment.
\end{abstract}

\footnotetext{
* Institute for Empirical Research in Economics, University of Zurich, Bluemlisalpstr. 10, 8006 Zurich, Switzerland, emails: efehr@iew.unizh.ch, goette@econ.berkeley.edu. We thank our discussants, Philipp Harms and Jordi Gali, and the participants at the 2002 JME / Study Center Gerzensee Conference on Behavioral Macroeconomics for valuable comments. George Akerlof, Paul Devereux, William Dickens, Reto Föllmi, Rafael Lalive, Ulrich Müller, George Perry, John Shea, Robert Trachsel, Michael Waldman, Beth Ann Wilson and Josef Zweimüller provided valuable comments on an earlier version of this paper. We benefited from discussions in seminars at the Universities of Zurich, Chicago, Bern, the Brookings Institution, the NBER Macroeconomics and Individual Decision Making Conference, and the ZEW Workshop Empirical Labor and Industrial Economics. We gratefully acknowledge financial support from the Swiss National Science Foundation, grant no. 1267751.02 .
} 


\section{Introduction}

The extent and the nature of downward nominal wage rigidity is likely to have strong implications for the functioning of the labor market and for questions of monetary policy. There are several reasons why firms may be reluctant to cut nominal wages. Firms may be constrained by efficient nominal wage contracts (MacLeod and Malcomson 1993, Holden 1999), by the existence of nominal loss aversion (Kahneman and Tversky 1979, Genesove and Mayer 1998) or by fairness standards (Kahneman, Knetsch and Thaler 1986, Agell and Lundborg 1995, Campbell and Kamlani 1997, Bewley 1999, Fehr and Falk 1999).

In this paper we examine two important unresolved questions in the empirical literature on nominal wage rigidity. First, there is, to our knowledge, no information regarding the rigidity of nominal wages in an environment of low nominal GDP growth. This question is important because in an environment with high average nominal growth there is little need to cut nominal wages and, hence, nominal wage rigidity - if it exists - has probably no big real effects. In contrast, in a low-growth environment wage rigidity may well be a binding constraint on wage setting for large segments of the work force. Hence, non-negligible real effects of nominally rigid wages are much more likely in an environment with low nominal GDP growth. However, little is known about the behavior of wages in this situation.

Second, there is little empirical support for the claim that nominal wage rigidity affects the real side of the economy. Yet, such knowledge is important because even if nominal wage cuts are frequently inhibited by nominal rigidity, it cannot be taken for granted that this causes real effects. The reason is that many labor relations are long-term so that the employer could, in principle, smooth the time path of individual wages without affecting the expected marginal costs of labor. For example, in a long-run employment relation a worker could pay for the absence of wage cuts in this year by lower wage increases in future years such that the present value of his labor costs would remain unaffected. From applications of the theory of repeated games to long run labor relations it is, however, known that these relations are characterized by infinitely many equilibria (MacLeod and Malcolmson 1989). Therefore, it is far from obvious that the equilibria with wage smoothing are the relevant ones. Ultimately, it is thus an empirical question whether widespread nominal wage rigidity will be associated with real effects.

Due to the lack of data previous studies were forced to examine the existence of nominal wage rigidity in an environment with quite large average growth rates of nominal GDP. The early studies by McLaughlin (1994) and Lebow, Stockton, and Washer (1995) found little 
evidence. Further studies by Akerlof, Dickens, and Perry (1996), Card and Hyslop (1996) and Kahn (1997) report more favorable evidence and two recent papers found quite strong evidence for downward rigidity (Altonji and Devereux 1999, Lebow, Saks and Wilson 1999). However, since all these studies used US data from the last four decades and since nominal GDP growth has been quite high during this time period it is difficult, if not impossible, to draw reliable inferences about the behavior of nominal wages in a low-growth environment from these studies. For example, between 1965 and 1998 there are only 3 years with a nominal GDP growth of less than 5 percent in the US. Gordon (1996) and Mankiw (1996) have forcefully argued that it is very problematic to infer from the presence of nominal wage rigidity in a high-growth environment that wages will also exhibit nominal rigidity in a lowgrowth environment. The reason is that the microeconomic behavior of workers and firms may well change in response to the change in the macroeconomic environment. "The ... attempt, to reason from evidence on nominal wage rigidity in an environment of rapid positive average nominal wage change to a hypothetical situation of zero average nominal wage change is subject to the Lucas critique. If the macroeconomic environment were different, microeconomic behavior would be different. Nominal wage reductions would no longer be seen as unusual if the average nominal wage was not growing. Workers would not see them as unfair, and firms would not shy away from imposing them." (Gordon, 1996, p. 62). If this argument is valid there would be little reason to be concerned about nominal wage rigidity because in a high-growth environment it is likely to have little impact on employment while in a low-growth environment nominal rigidity will be absent.

The empirical results presented in this paper challenge, however, the above argument. We provide evidence for the presence of strong nominal wage rigidity in an environment with sustained low nominal growth. Our study is based on the Swiss experience between 1991 and 1997. During this period Switzerland experienced inflation rates and real GDP growth rates close to zero in several consecutive years and in three years real growth was even negative. Between 1992 and 1997 nominal GDP growth was always below 2.6 percent. Thus, there was plenty of time for individual agents to adjust their behavior to this macroeconomic environment. Yet, our results indicate that the low inflation environment reduced the reluctance to cut nominal wages by only very little. This decrease was far too small to accommodate the greater need for nominal wage cuts when inflation approached zero. Therefore, instead of a decrease in the quantitative relevance of nominal wage rigidity we even observe an increase over time. For example, in 1991, when nominal GDP growth was still 5.2 percent, nominal rigidity prevented wage cuts for one third of the job stayers and the average prevented wage decrease for these workers was 2.7 percent. In contrast, in 1997, after 
5 years of very low nominal growth, the fraction of job stayers who did not receive wage cuts due to nominal rigidity was 62 percent and the average prevented wage decrease for these workers was 6.5 percent. These results leave little doubt that the rigidity of nominal wages is very persistent in these years. Moreover, our results also show that in the absence of nominal wage rigidity real wages would be quite flexible. This indicates that nominal wage rigidity is an important determinant of real wages in an environment with low nominal GDP-growth.

In view of this result it is interesting to ask whether nominal wage rigidity is associated with important real effects. Previous research has either not dealt explicitly with this question or has found no strong effects. At the micro-level Altonji and Devereux (1999) found evidence that workers who are protected by a nominal wage floor are less likely to quit. Whether nominal rigidity also affects layoffs, promotions, and relative wage growth remains, according to these authors, an open question. For the macro-level there seems to be even less evidence. To our knowledge, so far there exists no evidence suggesting that nominal wage rigidity is associated with higher unemployment. The recent paper by Lebow, Saks and Wilson (1999) even poses a so-called micro-macro puzzle. These authors found that despite the large wage sweep-ups caused by nominal wage rigidity in the US in the 1980s the unemployment rate even decreased in this period. Moreover, the paper reports that the measure of nominal rigidity is insignificant in Phillips curve estimates suggesting that nominal rigidity may be unimportant at the macro-level. However, in view of our arguments above it could also be the case that nominal wage rigidity has only small effects in an environment with relatively high nominal growth while it may well cause important real effects in a low-growth environment.

To examine whether nominal wage rigidity is associated with unemployment we have computed the average wage sweep-up caused by nominal rigidity for every canton ${ }^{1}$ and every industry in Switzerland in each year between 1991 and 1997. This enables us to see whether the wage increasing effect of nominal rigidity is related to the unemployment rates in the different cantons and industries. Our analysis yields a striking result: In every single canton and in most industries we observe a positive relation between the unemployment rate and the average wage sweep-up caused by nominal rigidity. A plausible interpretation of this result is that the wage sweep-ups indeed represent sweep-ups in labor costs, which induce firms to lay off workers.

The remainder of the paper is structured as follows: Section 2 discusses the characteristics of the Swiss labor market. Section 3 provides descriptive evidence on wage rigidity from

\footnotetext{
${ }^{1}$ Switzerland is a highly decentralized federation that consists of 26 cantons. The cantons are the primary political units comparable to the federal states in the US.
} 
personnel files and Section 4 shows descriptive evidence from representative random samples. Section 5 discusses the empirical model of wage changes applied in our paper. Section 6 shows to what extent nominal rigidity persists in our low growth environment and discusses the real consequences on unemployment. Section 7 concludes the paper.

\section{Characteristics of the Swiss Labor Market}

The Swiss labor market is one of the least regulated and least unionized labor markets in Europe. In Switzerland employers have, for example, the legal possibility to enforce wage cuts by proposing a lower nominal wage to incumbent workers. If a worker refuses to accept the new wage, the law allows the employer to fire the worker. Due to these characteristics the Swiss labor market is perhaps closer to the US labor market than to the labor markets in most other European countries. Despite the employers' opportunities of firing individual workers nominal wage rigidity may nevertheless occur if behavioral forces like nominal fairness standards and nominal loss aversion are sufficiently strong. For our purposes, the most important feature of the Swiss situation is that both inflation and real GDP growth was very low in the period under consideration. Between 1991 and 1993 real GDP growth was even negative and between 1994 and 1996 real growth was always less than 0.5 percent. Low real GDP growth implies that average real wage growth is moderate. Therefore, structural changes in the economy are likely to be associated with the necessity to cut the real wages of many workers. This downward pressure on the real wages of many workers is translated into downward pressure on nominal wages if inflation rates are low. In Switzerland the rate of inflation was never above 1.6 percent between 1993 and 1997. This is a very good environment for the examination of nominal wage rigidity. The downward pressure on the nominal wages of many workers means that firms face a strong temptation to cut the nominal wages of these workers, and, consequently, nominal wage cuts should become more customary. This, in turn, is the ideal situation to examine whether nominal wage rigidity indeed erodes. When, if not in this situation, can we expect an erosion of nominal wage rigidity? On the other hand, if nominal rigidity persists, this is the ideal environment for the study of the real consequences of nominal rigidity because nominal rigidity prevents many real wage cuts.

It is instructive to compare the macro-environment in this study with the macro-environment in previous studies of nominal wage rigidity (see Table 1). In our study the median nominal 
GDP growth is 2.2 percent during the sample years while in the other studies it varies between 5.7 percent and 11.3 percent. Moreover, to study the persistence of nominal rigidity in a low nominal growth environment it is necessary that nominal growth rates are low in several consecutive years. It is unlikely that nominal rigidity erodes just because nominal GDP growth drops below, say, 3 percent in a single year. Table 1 shows that previous studies could not address this question because - except for the study by Akerlof, Dickens and Perry (1996) - nominal growth was never below 5.2 percent in two or more consecutive years. In contrast, in our sample period it was always below 5.2 percent. Likewise, in all studies, including the one by Akerlof, Dickens and Perry (1996), nominal growth was never below 2.6 percent in two or more consecutive years while in our study this was the case in 6 consecutive years. ${ }^{2}$

\section{Descriptive Evidence from Personnel Files}

The ideal data set for examining nominal wage rigidity would be a representative sample of firms' personnel files including precise information on wages, individuals' productivity and other individual characteristics. Unfortunately, to our knowledge there is no study with such a data set. Although less informative it is still useful to examine non-representative firm-level information. ${ }^{3}$ We obtained personnel records from a large and a medium-sized Swiss firm. Firm $\mathrm{A}$ is a large firm in the service industry with approximately 10,000 employees. The available personnel records cover the period from 1993 to 1999. For both firms wages are calculated as total compensation divided by hours in the contract. Average wage growth in Firm A was 3.8 percent (s.d.: 5.3 percent). Firm B is a medium-sized firm in the service industry with a declining activity in manufacturing. The records of Firm B start in 1984 and end in 1999. In this firm employment drops from about 2000 in the 1980s to 1000 in 1998, from where it started to rise again ${ }^{4}$. Wages grew on average by 5.7 percent (s.d.: 5 percent) in Firm B.

Figure 1 displays the distribution of wage changes (measured in log wage differences) in the two firms for the periods 1993 - 1999 and 1984 - 1998, respectively. The striking feature of

\footnotetext{
${ }^{2}$ In the Akerlof et al. study nominal GDP growth was 3.9 percent in 1960 and in 1961 . Then it rose to 7.5 percent. Thus this is also not the kind of environment where one would expect nominal rigidities to erode. The lowest nominal growth rate in the US between 1960 and 1998 was 3.2 percent in 1991.

${ }^{3}$ Interesting evidence from the personnel files of a large firm is reported in Baker, Gibbs and Holmström (1994) and Wilson (1999).

${ }^{4}$ The reason is that Firm B closed its manufacturing plants, which was accompanied with a large employment decrease, many of which were dismissals.
} 
both distributions is, that there are almost no wage cuts. In Firm A (N=35,779), only 1.7 percent of all observations are wage cuts. In Firm B $(\mathrm{N}=20,236)$, the fraction is even lower (0.4 percent). Both distributions exhibit a discontinuity at zero that could hardly be more pronounced. If we restrict our attention to the years with low nominal GDP growth the picture is essentially the same. Between 1993 and 1997 average nominal wage growth was also 3.8 percent in Firm A and the percentage of negative wage changes was 1.5. Firm B experienced 4.2 percent average nominal wage growth in this period and the percentage of wage cuts was again 0.4 percent. Therefore, irrespective of the period considered nominal wage cuts are extremely rare in these firms. These data are, thus, certainly consistent with the view that employers are reluctant to cut nominal wages. Yet, it is unclear to what extent the wage change regularities in these firms are representative for the whole economy.

\section{Descriptive Evidence from Representative Samples}

To get representative information on the extent of nominal rigidity we examine two large data sets. The first data source is the Swiss Labor Force Survey (SLFS) for the years $1991-1998$. The SLFS is a rotating panel that follows individuals for five years. In total, the SLFS provides 21,144 wage change observations. The second data source is a large random sample from the Social Insurance Files (SIF). The SIF contains information about all employees in Switzerland. This sample gives us 140,628 observations of wage changes and covers essentially the same time period as the SLFS-data ${ }^{5}$. The major advantage of examining both data sets is that this provides a very useful robustness check of our results. Below we will show that both data sources have their specific advantages and disadvantages. Hence, if both data sources nevertheless lead to similar results we can be more confident that the results are robust.

In both data sources we consider non-self employed individuals who stayed with the same firm for at least one year. We call these individuals "job stayers". We trimmed both samples by excluding all observations with an absolute wage change above 50 percent. This is motivated by the concern that for job stayers wage changes exceeding 50 percent are utterly implausible. In both data sets we lose approximately 3 percent of the observations when we apply this criterion. However all our conclusions remain qualitatively identical and

\footnotetext{
${ }^{5}$ The Social Insurance Files are December to December data, while the SLFS is conducted in May. Hence, referring to wage changes in e.g. 1993, we mean wage changes between May 1993 and May 1994 for the SLFS and wage changes between December 1992 and December 1993 for the SIF.
} 
quantitatively very similar if we use the whole sample for our estimates. For the SLFS-data our measure of wages is total compensation (net of social security contributions) divided by hours specified in the labor contract. For the SIF-sample we use a different measure of wages as discussed below.

The advantage of the SLFS is that it provides extensive information on the characteristics of individuals like, e.g., tenure, labor market experience, education levels, gender, age, nationality, etc. The disadvantage is that surveys are likely to be distorted by reporting errors. The advantage of the SIF-data is that all financial transactions between firms and workers are recorded in the Social Insurance Files. Hence, reporting error is not an issue. The earnings information obtained from the SIF is accurate. In addition, the SIF-sample is comfortably large. Since the SIF data covers the same period of time as the SLFS-data, we can replicate the empirical analysis we conduct with the SLFS. We should also mention that the SIF-data have three problems. First, it is impossible to identify job stayers with absolute certainty. We only consider those workers in the SIF-sample who were insured by the same local social insurance agency in two consecutive years since these are most likely to be job stayers. However, if a worker moves to another employer, but both employers are associated with the same local agency, the individual may still be included in our sample. Thus, we may wrongly include job movers in our SIF-sample, which could understate the true degree of nominal wage rigidity. Second, we have precise information on total compensation per year but not on hours worked. Our measure of observed wage changes in the SIF-sample is, therefore, given by the changes in total compensation per year. Hence, temporary variations in hours, which arise, e.g., through different amounts of overtime in two years, look like a 'wage change' in our sample. As we will illustrate below, this can generate a substantial number of observations that look like a wage cut but which are indeed reductions in actual hours worked. This is particularly important for the time period considered because in a recession firms may use working time reductions as an alternative to nominal cuts. Third, the available worker characteristics in the SIF-sample are not the same as in the SLFS. They include age, nationality, gender, details on the agency that recorded the payment and the period of time to which it applies.

Figure 2 summarizes the distribution of nominal wage changes (measured in log wage differences) for job stayers in Switzerland between 1991 and 1997. Consider first the figure on the left which displays the histogram obtained from the SLFS. This histogram exhibits the following properties: 
1. There is a spike at zero: The largest bin is the one containing no and small, but positive nominal wage changes (between zero and 2 percent). ${ }^{6}$

2. There is an asymmetry in the distribution of wage changes. Negative wage changes are observed less frequently than positive wage changes.

3. Despite the asymmetry there is a considerable fraction of negative wage changes.

Compare this to the right panel of Figure 1a, which is based on the SIF data using identical bins. Three features deserve to be mentioned here:

1. The SIF distribution exhibits less dispersion, i.e., it is more centered around zero than the SLFS distribution. While, e.g., 59 percent of all observations in the SIF are between zero and 10 percent, the corresponding figure for the SLFS is only 45 percent.

2. The asymmetry between positive and negative wage changes is much more pronounced in the SIF sample. There is a striking discontinuity around zero and the pile-up of observations just above zero is very pronounced.

3. The fraction of negative wage changes is considerably smaller in the SIF-sample.

Table 2 provides additional information on wage changes in our two data sources together with the inflation rate (measured by CPI changes) and real GDP growth. The table shows that the sharp decrease in the rate of inflation at the beginning of the period considered is associated with more observed wage cuts and more zero wage changes in the SLFS. The fraction of job stayers with a zero nominal wage change rises from 5 percent in 1991 to 15 percent in 1997. The fraction who reported wages that implied wage cuts is, in general, quite high. It also rises from 20 percent in 1991 to 33 percent in 1997. Interestingly, however, the fraction of workers with wage cuts is always lower in the SIF-sample than in the SLFSsample. This suggests that reporting error is important in the labor force survey: Imagine that the distribution of true wage changes has no, or only a few, negative entries. Assume further that reporting error is important. Then, as the distribution moves closer to zero over time, reporting error creates a larger number of negative observations. Therefore, we observe more wage cuts in the SLFS sample. Note that the fact that we cannot control for hours variation in the SIF sample only strengthens this argument because it is likely to produce false negatives in this sample, too, a point to which we return below.

\footnotetext{
${ }^{6}$ For the exact fraction of zero wage changes see Table 2.
} 
Figure 3 shows the evolution of the distribution of log wage differences over time, using the SIF sample. The sequence of distributions conveys the impression that the decline in inflation is associated with a rise in downward rigidity. Consider, first, the three panels for 1991, 1992, and 1993. In these years the distribution is - except for the small spike at zero - relatively symmetric around its median. The bins to the left and to the right of the median are of similar size. Compare this to the distribution of wage changes in the low inflation years 1995 to 1997 , where the median is much closer to zero. In these years there is a sharp discontinuity at zero and the distribution also exhibits a pronounced asymmetry around zero. Note also that there is only a relatively small increase in the frequency of negative wage changes during these years.

The upshot of the descriptive evidence in Table 2 and Figures 2 and 3 can be summarized as follows: The asymmetry in the distribution of wage changes and the spike at zero may be interpreted as an indication of nominal wage rigidity. Support for this interpretation is also provided by the fact that the asymmetry becomes much more pronounced over the years. However, the relatively large fraction of observed wage cuts in the SLFS and the SIF provide much less convincing evidence for nominal wage rigidity than the descriptive evidence from the personnel files. This raises the question whether the non-negligible number of observed wage cuts represent true wage cuts or whether they are mainly the result of reporting error (in the SLFS) or of unobserved hours variation (in the SIF). The much smaller number of observed wage cuts and the generally smaller dispersion of wage changes in the SIF suggests that reporting error is a serious problem in the SFLS. ${ }^{7}$ Thus, many of the observed wage cuts in the SLFS might be spurious. In addition, the absence of a direct measure for working time in the SIF may pollute the SIF data in a similar way as reporting error pollutes the SLFS data.

In order to gain some insights into the potential role of unobserved variations in working time we take advantage of the fact that the personnel file of Firm B provides precise information on overtime payments for each individual. Thus, we can compute the distribution of wage changes in Firm B in the presence and in the absence of controlling for overtime payments. The results are presented in Figure 4. The first panel reproduces the true distribution of wage changes in Firm B, i.e., overtime payments are not included, for the period 1993 to $1998 .{ }^{8}$ In the second panel, we deliberately add overtime payments to the compensation to calculate 'polluted' wage changes as we would observe them in the SIF. The distribution of 'wage'

\footnotetext{
${ }^{7}$ The fact that the distribution of positive wage changes in the two firms above is much less dispersed than the distribution in the SLFS is also compatible with this conjecture. In both firms 89 percent of all observations are between zero and ten percent while in the SLFS only 45 percent of the observations are in this range.

${ }^{8}$ We constrain the sample, because information on overtime payments is only available for this period.
} 
changes in the second panel now contains a sizeable fraction of spurious wage cuts (7.6 percent) and is less centered around zero compared to the true distribution. While this exercise does not replicate the moments of the SIF-sample perfectly, it suggests that unobserved working time variations may well cause a sizable fraction of spurious wage cuts in the SIFsample. Note also that average wage growth is relatively high in Firm B, hence unobserved hours variation would generate even more false negatives in a low-growth firm.

\section{An Empirical Model of Wage Changes}

The upshot of the previous discussion is that we need an econometric model that explicitly allows for the presence of measurement error so that one can separate true wage changes from wage changes that merely reflect reporting error or reductions in actual hours worked. The general idea behind our model is that there may be reasons - e.g., efficient nominal wage contracts, nominal fairness standards and nominal loss aversion - that render nominal wage cuts costly for the firms. Therefore, firms will not implement all desired wage cuts and, as a consequence, there will be a difference between the desired or "notional" wage cuts and actually implemented wage cuts. However, the larger the notional wage cut the more likely it is that the benefits will outweigh the costs. Hence, for individual $i$ at time $t$ there may exist a threshold value $c_{i t}$, which, together with the notional wage cut, determines whether the actual wage will be cut or not. If the notional wage cut is below $c_{i t}$ the firm will not implement the cut but if the notional cut is above $c_{i t}$ the pay reduction will be implemented. Our main focus is to estimate the mean $\mu_{c}$ and the variance $\sigma_{c}$ of the distribution of thresholds. Since we also estimate the distribution of measurement errors and the distribution of notional wage changes we can compute the frequency of true wage cuts and the share of workers who is affected by nominal rigidity. Workers are affected by nominal rigidity if their notional wage change is negative but since the notional wage cut is below their threshold $c_{i t}$ their actual wage is not cut. The general structure of the estimated model is as follows:

$$
\Delta y_{i t}=\left\{\begin{array}{ccc}
x_{i t}{ }^{\prime} b+e_{i t}+m_{i t} & \text { if } & x_{i t}{ }^{\prime} b+e_{i t} \geq 0 \\
m_{i t} & \text { if } & -c_{i t} \leq x_{i t}{ }^{\prime} b+e_{i t}<0 \\
x_{i t}{ }^{\prime} b+e_{i t}+m_{i t} & \text { if } & x_{i t}{ }^{\prime} b+e_{i t}<0, x_{i t}{ }^{\prime} b+e_{i t}<-c_{i t}
\end{array}\right.
$$

where $\Delta y_{i t}$ is the observed log nominal wage change of individual $i$ in period $t, x_{i t}{ }^{\prime} b+e_{i t}$ is the notional nominal wage change that would be implemented in the absence of downward nominal wage rigidity, $x_{i t}$ is a set of observable variables that are likely to affect wage 
growth, $e_{i t}$ represents the usual error term, and $m_{i t}$ denotes the measurement error, which can be interpreted as reporting error in the SLFS and unobserved hours variation in the SIF.

In the presence of nominal inertia and measurement error observed wage growth is not only determined by $x_{i t}{ }^{\prime} b+e_{i t}$. In addition, the mean and the standard deviation of the distribution of wage cut thresholds, $\mu_{c}$ and $\sigma_{c}$, and the standard deviation of $m_{i t}, \sigma_{m}$, are important. Therefore, observed wage changes can, in principle, fall into one of the following three regimes:

(i) If the notional wage change $x_{i t}{ }^{\prime} b+e_{i t}$ is positive there are no forces that inhibit this wage change, i. e., we observe $x_{i t}{ }^{\prime} b+e_{i t}+m_{i t}$ in the data (see (1) above) and the likelihood of this occurring is

$$
f_{e+m}\left(\Delta y_{i t}-x_{i t}{ }^{\prime} b \mid x_{i t}{ }^{\prime} b+e_{i t}>0\right)
$$

where $f_{e+m}(\cdot)$ is the density of the sum of $e$ and $m$.

(ii) If $x_{i t}{ }^{\prime} b+e_{i t}$ lies between $-c_{i t}$ and zero, the firm will not cut the worker's wage but give him a pay freeze instead. The observed 'wage change' is then entirely due to unobserved variation. Hence the likelihood of falling in this regime only depends on the distribution of $m$ and is given by

$$
f_{m}\left(\Delta y_{i t} \mid-c_{i t}<x_{i t}{ }^{\prime} b+e_{i t}<0\right)
$$

Note that we do not assume that sufficiently small notional wage cuts result in a pay freeze. Whether a notional wage cut is executed or not depends on the distribution of $c_{i t}$, whose parameters are jointly estimated with all other parameters of the model.

(iii) If the notional wage cut is larger than $c_{i t}$, the firm will implement the wage cut. The conditional density for this event is

$$
f_{e+m}\left(\Delta y_{i t}-x_{i t}{ }^{\prime} b \mid x_{i t}{ }^{\prime} b+e_{i t}<-c_{i t}, x_{i t}{ }^{\prime} b+e_{i t}<0\right)
$$

Since it cannot be observed which regime generated a particular observation, the likelihood of an observation sums up to

$$
\begin{aligned}
l_{i t}= & f_{e+m}\left(\Delta y_{i t}-x_{i t}{ }^{\prime} b \mid x_{i t}{ }^{\prime} b+e_{i t}>0\right) \cdot \operatorname{Pr}\left(x_{i t}{ }^{\prime} b+e_{i t}>0\right) \\
& +f_{m}\left(\Delta y_{i t} \mid-c_{i t}<x_{i t}{ }^{\prime} b+e_{i t}<0\right) \cdot \operatorname{Pr}\left(-c_{i t}<x_{i t}{ }^{\prime} b+e_{i t}<0\right) \\
& +f_{e+m}\left(\Delta y_{i t}-x_{i t}{ }^{\prime} b \mid x_{i t}{ }^{\prime} b+e_{i t}<-c_{i t}, x_{i t}{ }^{\prime} b+e_{i t}<0\right) \cdot \operatorname{Pr}\left(x_{i t}{ }^{\prime} b+e_{i t}<-c_{i t}, x_{i t}{ }^{\prime} b+e_{i t}<0\right)
\end{aligned}
$$


We assume that $e$ and $m$ are i.i.d. normal and estimate the parameters by maximum likelihood. ${ }^{9}$

Intuitively, our estimator examines whether individuals with low predicted real wage growth in high-inflation years have on average higher wage growth than expected (given their characteristics) during low-inflation years since the required nominal wage cut could not take place. This, together with the assumption of symmetric measurement error, identifies the extent of downward nominal wage rigidity. Notice that this identification is not biased towards finding downward nominal wage rigidity. If predicted versus actual wage growth in low-inflation years do not differ from predicted versus actual wage growth in high-inflation years, the estimator will conclude that there is no - or very little - downward nominal wage rigidity and leave this part of the model unidentified.

Model (1) is similar to, but more general than, the model in Altonji and Devereux (1999). A main difference between our approach and the one taken by Altonji and Devereux is that we allow for individual heterogeneity in the thresholds $c_{i t}$ whereas Altonji and Devereux impose the restriction that the threshold is the same for all workers. There is evidence (Shafir, Tversky and Diamond 1997; Fehr and Gächter 2000) indicating that individuals differ with regard to their fairness standards and their degree of money illusion. Thus, individual heterogeneity may be important so that some workers may have flexible wages while others have rigid wages. In our model, those workers who have a negative threshold $\left(c_{i t}<0\right)$ exhibit perfectly flexible wages. Note also that our model nests the model of Altonji and Devereux as a special case. If the variance of $c_{i t}$ goes to zero the two models become identical.

In addition to allowing for individual heterogeneity we also allow for a nonzero correlation between the error term $e_{i t}$ and the individual thresholds $c_{i t}$ and we estimate the value of this correlation. This is potentially important because there is considerable survey evidence that nominal wage cuts do occur when a firm is in financial distress. Several studies (e.g., Bewley 1999, Campbell and Kamlani 1997) document this. Individuals are more likely to accept wage cuts when their firm is in trouble. Allowing for a nonzero correlation between $e_{i t}$ and $c_{i t}$ offers a simple way of incorporating this feature because changes in firm productivity are presumably an important component of $e_{i t}$. Based on the survey evidence one would, therefore, expect that if $e_{i t}$ is very low (negative) a worker's threshold $c_{i t}$ is very small, too, so that the correlation between $e_{i t}$ and $c_{i t}$ is positive.

\footnotetext{
${ }^{9}$ In an appendix, that is available on request, we derive the explicit expression for (2), that can be directly used for estimation purposes.
} 
We also allow for some heterogeneity with regard to reporting error (in the SLFS) and overtime work (in the SIF sample). We assume that in every year, a fraction $p$ (that will be estimated) of the individual data has no measurement error, but that the rest of the sample draws a normally distributed error. This means that in the SLFS a fraction $p$ of all respondents states the correct income, but the rest makes normally distributed errors. In analogy, in the SIF sample, a fraction $p$ of all individuals has no variation in hours between the previous and the current year.

In our empirical estimates below it is important that $x_{i t}$ contains variables that capture business cycle variation in wages, and individual characteristics correlated with wage growth. We use the change in the regional unemployment rate as well as year fixed effects as our business cycle variables. Variables that systematically affect wage growth across workers, are labor market experience, age, tenure, and observable skills of worker $i$. The inclusion of these variables into our wage growth equation is suggested by many papers (e.g., Topel 1991). It is generally recognized that the experience-earnings profile and the tenure-earnings profile is concave, i.e. wages grow at a decreasing rate with experience and tenure. Likewise, several studies indicate that wage growth is different for different categories of workers (e.g. Baker, Gibbs and Holmström 1994). As an additional control we also included the firm size. ${ }^{10}$ In our estimates with the SIF sample we use a worker's age as a proxy for experience. In addition, a foreigner dummy variable, as well as an interaction term with log age, captures the systematic differences in experience and job status between Swiss employees and employees from other countries.

Our approach nests both the case of perfect wage flexibility and the case of perfect wage rigidity. As $\mu_{c}$ approaches minus infinity, there is no downward wage rigidity. In this case the model collapses to a simple OLS regression of $\Delta y_{i t}$ where only the sum of $e$ and $m$ is identified. If, at the other extreme, $\mu_{c}$ is very large (and $\sigma_{c}$ finite), there are no true wage cuts and the third regime drops out. Hence, the model nests both extreme cases, and any intermediate one. It allows for resistance only towards small wage cuts, or larger ones. It provides joint estimates of the distribution governing the cost $c_{i t}$ of cutting nominal wages, and the variance of the distribution of $e$ and $m$. If we estimate a negative $\mu_{c}$ that is very large in absolute value, most observed wage cuts represent true wage cuts. However, if we estimate large enough positive values of $\mu_{c}$, most observed wage cuts do not represent true wage cuts, that is, measurement error is more pervasive.

\footnotetext{
${ }^{10}$ A recent study by Winter-Ebmer and Zweimüller (1999) reports firm-size effects for Switzerland that are comparable in size to those in the US.
} 
Finally, our model also enables us to examine important determinants of $\mu_{c}$ (and $\sigma_{c}$ ). Instead of imposing the restriction (as in model (1)) that $\mu_{c}$ is the same for all workers in all years we can allow for year-specific $\mu_{c}$ 's or for different $\mu_{c}^{\prime}$ s for different groups of workers. In particular, by estimating year-specific $\mu_{c}$ 's we can observe whether $\mu_{c}$ is lower in low-inflation years, which would provide direct evidence for the validity of the conjecture put forward by Gordon (1996) and Mankiw (1996). Also, by allowing variations of $\mu_{c}$ across different categories of workers we can examine, for instance, whether $\mu_{c}$ is different for full-time and part-time workers or for job stayers and job movers. This question is important insofar as the role of fairness standards is presumably more relevant the stronger the attachment of workers to their firm. If this argument is true we should observe more wage rigidity for job stayers than job movers and for full-time workers compared to part-time workers.

\section{Results}

In this section, we discuss the results obtained by estimating the above model. We first present the overall tests for the presence of downward nominal wage rigidity. We then evaluate the stability of these estimates as inflation becomes very low. Next, we assess the implications of the model for different types of workers and the extent to which downward wage rigidity prevents real wage cuts. Finally, we examine the consequences of nominal wage rigidity for regional and industry-specific unemployment.

\subsection{Are Wages Flexible?}

The basic results for both samples are displayed in Table 3. For both samples we estimated 3 different models. Model (1) estimates $\mu_{c}$ under the assumption that there is no heterogeneity in individual thresholds $\left(\sigma_{c}=0\right)$ and that the correlation between $e_{i t}$ and $c_{i t}$, denoted by $\rho_{e c}$, is zero. In model (2) we also allow for $\sigma_{c} \neq 0$ and in model (3) we estimate both $\sigma_{c}$ and $\rho_{e c}$. In all regressions we control for year effects by including year-dummies and in the SLFS sample we also can control for firm size effects. The major result of Table 3 is that regardless of which data set we use and regardless of which model we take, the mean threshold $\mu_{c}$ is positive and significant indicating the existence of nominal wage rigidity. Moreover, in all models where we estimated $\sigma_{c}$ the value of $\sigma_{c}$ is significant so that a large percentage of individual thresholds is positive. In model (2) for the SIF sample, for instance, the mean threshold is 0.383 and the standard deviation is 0.21 implying that only about 3 percent of all individuals 
have no positive thresholds. Thus, only about 3 percent of the individuals have perfectly flexible wages whereas for 97 percent of the individuals nominal wages exhibit some rigidity. Moreover, according to model (2) 91 percent of the individuals have thresholds such that only if the notional wage cut is above 10 percent the actual wage will be cut. The quantitative importance of nominal wage rigidity is very similar, regardless of whether we use the estimates from the SLFS or the SIF, as can be seen in the remaining columns of Table 3.

The relevance of nominal wage rigidity can be inferred from rows 4 and 5 of Table 3, which show the quantitative implications of the estimated distribution of thresholds for the frequency of true wage cuts and for the share of workers who would have experienced wage cuts in the absence of nominal rigidity. According to the estimates where $\sigma_{c}$ is unconstrained (models (2) and (3)) the frequency of true wage cuts is between 7 and 8 percent in the SLFS sample and between 6 and 7 percent in the SIF sample. The share of workers who is affected by nominal rigidity, i. e., those who experience notional but not actual wage cuts, varies between 48 and 54 percent. Thus, the quantitative importance of nominal rigidity is high and very robust across models and across data sets. Our estimates of model (3) also reveal that $\rho_{i t}$ is highly significant, positive and of the same size for both data sets. This is consistent with the view that negative idiosyncratic productivity shocks render people more willing to accept a nominal wage cut.

The extent of measurement error in our survey data is substantial although it is lower than expected. Our estimate of the standard deviation $\sigma_{m}$ of the measurement error in the SLFSsample is between 6 and 7 percent (see second page of Table 3). This is low compared to what validation studies of labor force surveys found for the US (see Angrist and Krueger, 1999 for a survey). The standard errors obtained from validation studies for the US are never below 10 percent, and sometimes considerably larger. In the SIF-sample the measurement error due to overtime variations is between 3 and 4 percent. These numbers indicate that it is important to take measurement errors into account to generate a true picture of nominal wage rigidity.

What are our estimates for the determinants of the notional wage changes? We find that a rise in experience lowers wage growth (see the estimates for the SLFS sample in Table 3). The estimated coefficient is negative and highly significant. Increasing labor market experience from one to ten years decreases wage growth by 2.7 percent. Table 3 also shows that a rise in tenure decreases wage growth. The tenure effect is roughly one third of the size of the experience effect. Note that these estimates of the tenure and the experience effect control for the potentially confounding impact of nominal wage rigidity because they take the truncation of wage changes below nominal zero (and above $-c_{i t}$ ) into account. Since our estimates of $\mu_{c}$ 
and $\sigma_{c}$ indicate a substantial amount of nominal inertia, estimates of the tenure and the experience effect that do not control for nominal inertia are likely to be confounded. ${ }^{11}$ Table 3 also indicates that the position of workers in the firm's hierarchy is important for wage growth. If the individual is a superior, wage growth is higher while if the individual is a member of the higher management wage growth is lower. ${ }^{12}$

We also find evidence that the change in the regional unemployment rate causes a substantial reduction in nominal wage growth. Our estimates imply that a one percentage point increase in unemployment growth reduces wage growth by at least 0.7 percentage points in the SLFS sample and by 0.8 percentage points in the SIF. The estimates are thus very robust across samples and indicate that wages would be quite flexible in the absence of downward wage rigidity. We also experimented with the level of the regional unemployment rate in our regressions. However, while the change in the unemployment rate has a sizable and significant impact on wage growth, the coefficient of the unemployment rate is always rather small and insignificant. We would like to emphasize here that, if one does not control for the presence of downward rigidity, the effect of unemployment changes on wage changes is not significant: In OLS-regressions, that disregard the potential truncation of wage changes below nominal zero (and above $-c_{i t}$ ), the coefficient of unemployment changes is not significant, i.e., one is led to the wrong conclusion that unemployment growth does not affect wage growth. This shows the importance of taking into account the presence of nominal rigidity.

For the SIF-sample we find that wage growth strongly declines with age as indicated by the negative and highly significant coefficient on log age. The SIF-estimates also shows that wage growth is smaller for foreign workers, reflecting most likely systematic differences in job status between Swiss and Non-Swiss employees. In addition, the positive coefficient on the interaction term between foreigner status and age indicates that wage growth declines less for Non-Swiss employees. We also conducted several regressions in which we included a gender dummy and interactions between gender and age (see Table A1 in the appendix). However, the inclusion of these control variables has little impact on the estimated distribution of thresholds. $^{13}$

\footnotetext{
${ }^{11}$ If we conduct OLS regressions not controlling for the presence of nominal wage rigidity, the tenure and the experience profiles are, in general, flatter.

${ }^{12}$ A superior is defined as an employee who has the power to direct the activities of several other employees without being a member of higher management.

${ }^{13}$ For the SLFS sample we also experimented with education variables. In the period under consideration their impact on wage growth was, however, insignificant and they did not change $\mu_{c}$ and $\sigma_{c}$. In view of the severe recession of the Swiss economy during this time it is not surprising that education had little impact on wage growth. The robustness of our estimates for $\mu_{c}$ and $\sigma_{c}$ is also indicated by the striking similarity of the results
} 


\subsection{Are Nominal Rigidities Easily Malleable?}

This section examines whether nominal wage rigidity tends to vanish in the course of a period with persistently low nominal growth. A natural way to test for this is to estimate yearspecific distributions of wage cut thresholds. On the basis of this information we then can calculate the share of individuals displaying some nominal rigidity (i.e., $c_{i t}>0$ ) and strong nominal rigidity (i.e., $c_{i t}>0.1$ ). Remember that inflation declined from roughly five percent in 1991 to zero percent in 1997. Real growth was slightly negative between 1991 and 1993 and slightly positive between 1994 and 1996. If nominal rigidity becomes weaker over time we should observe a declining impact of nominal rigidity. Table 4 provides our estimates of yearspecific values of $\mu_{c}$ and $\sigma_{c}$ relative to the value of $\mu_{c}$ and $\sigma_{c}$ in 1991. Table 4 also shows the percentage of workers exhibiting some $\left(c_{i t}>0\right)$ and strong $\left(c_{i t}>0.1\right)$ rigidity. Panels (a) and (b) in Figure 5 present the corresponding graphs. ${ }^{14}$ It is remarkable that all estimates of $\mu_{c}$ are positive and highly significant. For the SIF sample the share of individuals displaying strong rigidity is rather stable over the years and fluctuates between 88 and 92 percent (see Table 4 and Panel $b$ in Figure 5). For the SLFS sample the share declines from 92 to 82 percent between 1991 and 1996. In, 1997 the share is again at 92 percent (see Table 4 and Panel a in Figure 5). However, the overall prevalence of downward nominal wage rigidity (the fraction of individuals with $c_{i t}>0$ ) decreases somewhat from almost 100 percent to about 90 percent, in both the SLFS and the SIF sample.

To see whether this was enough to eliminate, or substantially reduce, the impact of downward nominal wage rigidity, we calculate the frequency of wage freezes and wage cuts for every year. The results are presented panels (c) and (d) in Figure 5. Irrespective of the data source, we get the same picture: There is essentially no or only a minor increase in the frequency of true wage cuts during the sample period and the share of workers who did not receive wage cuts due to nominal wage rigidity rises sharply in both samples. Thus, the small reduction in the resistance against wage cuts was not nearly large enough to lead to a meaningful increase

obtained from the SIF and the SLFS. In addition, the results in Table A1 in the appendix, where we interact the age profile fully with nationality and gender suggest that our estimates are rather stable. The results in columns (2) and (3) of Table A1 (in particular, the frequency of wage cuts and the share of workers experiencing wage freezes) are very close to the baseline results where we omit gender and most of these interactions.

${ }^{14}$ Recall that the SLFS is based on May-to-May data. Hence, we use May-to-May changes in the CPI measure of inflation. Analogously, we use December-to-December CPI changes whenever we use the SIF data. Therefore, inflation rates differ somewhat between panel (a) and (b) of Figure 5. 
in the number of nominal wage cuts. Quite to the contrary, the share of workers with wage freezes becomes twice as large during the period under consideration.

\subsection{Who is most affected?}

There are various reasons why nominal rigidity is likely to be different for different categories of workers. First, fairness standards that render nominal wage cuts costly are likely to arise through a history of repeated interactions between the worker and the firm. In the absence of such a history employers are less likely to be constrained by fairness standards. Therefore, it seems much easier to impose pay cuts on job movers than on job stayers. Second, for a firm the loyalty and work morale of full-time workers is, in general, more important than the loyalty and work morale of part-time workers. Moreover, the relevance of fairness standards is likely to be more important for workers with a greater attachment to the firm. Therefore, one would expect more wage rigidity among full-time workers. A third reason is related to the theory of efficient nominal wage contracts (MacLeod and Malcomson 1993). These contracts serve the purpose to protect the relation-specific investments of firms and workers efficiently. They are therefore more important for those workers who have more firm-specific human capital. Job stayers have, by definition, more firm-specific human capital than job movers. In addition, it seems likely that full-time workers have more specific human capital than part time workers so that efficient nominal wage contracts are more important for full-time workers. Therefore, the theory of efficient nominal wage contracts also suggests that nominal wage rigidity is more important for job stayers and for full-time workers.

The results regarding the differences between full-time and part time job stayers are displayed in Table 5. As argued above we find large differences between the two groups of employees. For part-time job stayers, the estimated mean threshold $\mu_{c}$ is 0.2 whereas for full-time job stayers it is 0.987 (see Table 5). Together with the estimated standard deviations this difference translates into sizeable differences of the impact of wage rigidity. For instance, only 6.8 percent of the full-time job stayers experience wage cuts while 15.5 percent of parttime job stayers had to accept wage cuts (see row 5 in Table 5). Likewise, for 57.2 percent of the full-time job stayers nominal wage rigidity constitutes a binding constraint, that is, there wages would have been cut in the absence of nominal rigidity, whereas this is the case for only 48 percent of part-time job stayers.

A similar picture emerges with regard to the difference between job stayers and job movers (see Table 5). Job stayers have a much larger average threshold, the frequency of true wage 
cuts is much smaller for them (8.4 percent versus 20.6 percent for job movers), and the share of workers for whom nominal rigidity is binding is much larger for job stayers (55.2 percent versus 40.6 percent). Thus, taken together, the evidence in this section is consistent with the above arguments that predict differences in nominal rigidity across these groups of workers. This lends support to the view that fairness standards and efficient nominal wage contracts are relevant factors behind the rigidity of nominal wages.

\subsection{The Consequences of Downward Nominal Wage Rigidity}

Our estimates provide two further pieces of information. First, we can calculate the average notional wage cut $x_{i t}{ }^{\prime} b+e_{i t}$ that did not occur because $-c_{i t}<x_{i t}{ }^{\prime} b+e_{i t} \leq 0$ holds. For brevity, we call this the average prevented wage cut and denote it by $E\left(\Delta w^{*}{ }_{i t} \mid-c_{i t}<\Delta w^{*}{ }_{i t} \leq 0\right)$, where $\Delta w_{i t}^{*} \equiv x_{i t}{ }^{\prime} b+e_{i t}$. Second, we can compute a measure of the average wage sweep-up due to downward wage rigidity $E\left(\Delta w_{i t}-\Delta w_{i t}^{*}\right)$ where $\Delta w_{i t}$ is the true wage change. The average wage sweep-up can be interpreted as the increase in average labor costs due to downward rigidity of nominal wages. If this interpretation is correct a rise in the average wage sweep-up should be associated with a rise in unemployment or a decline in employment in the different industries and cantons.

Panels (e) and (f) in Figure 5 exhibit the evolution of $E\left(\Delta w^{*}{ }_{i t} \mid-c_{i t}<\Delta w^{*}{ }_{i t}<0\right)$ for the job stayers. The panels show that downward nominal wage rigidity has less impact at the beginning of the period considered when inflation was still relatively high. At this time the prevented wage cut was roughly 2 percent in both data sets. This changes substantially in years where inflation rates are closer to zero. From 1993 onwards, the prevented wage reductions are, on the average, 5 percent or more. This shows again that nominal rigidity became increasingly important during the period of low nominal growth.

We now turn to the question whether downward nominal wage rigidity has consequences for the real side of the economy. For this purpose we compute the average wage sweep up $E\left(\Delta w_{i t}-\Delta w_{i t}^{*}\right)$ for every canton and every industry and relate them to the unemployment rate in the cantons and the industries. ${ }^{15}$ Since there are large variations in the level and in the changes of unemployment across cantons and across industries it is interesting to examine to

\footnotetext{
${ }^{15}$ In the following presentation (which is based on the SIF-sample) we concentrate on the relation between average wage sweep-up and the unemployment rate. However, the changes in the unemployment rate in our sample are almost exclusively driven by the changes in the employment level because labor supply was roughly constant. Therefore our examination also provides direct insights into the relation between employment and average wage sweep-ups across cantons and industries.
} 
what extent variations in the wage sweep-up can explain these variations in unemployment. Note that in our estimate of the wage sweep-up the rate of unemployment is not an explanatory variable. This is important because otherwise there would be a relation between wage sweep-up and unemployment by construction. ${ }^{16}$

In Figure 6a we plotted the relation between average wage sweep-up and unemployment rate separately for each canton with more than 1 percent of the labor force ${ }^{17}$. The figure conveys a striking message: In each canton we can observe an unambiguous positive relation between the wage sweep-up and the unemployment rate. In addition to Figure $6 \mathrm{a}$ we also ran the following regression:

$$
u_{j t}=\text { const. }+b E_{j t}\left(\Delta w-\Delta w^{*}\right)+e_{j t}
$$

where $u_{j t}$ is the rate of unemployment in canton $j$ and year $t$, and $E_{j t}$.) denotes the average wage sweep up in canton $j$ and year $t$. The results of this regression are presented in Panel A of Table 6. In the first column, we estimate equation (3). The OLS estimate of (3) yields a highly significant and large positive point estimate of 1.17 for $b$ : A one percent increase in the wage sweep-up increases unemployment by 1.17 percentage points. The $R^{2}$ of regression (3) indicates that variations in the wage sweep-up alone explain 49 percent of the variance in the unemployment rate. In the second to fourth column, we add cantonal and year fixed effects in a stepwise manner. The point estimate for $b$ remains almost unchanged and is again highly significant when we add cantonal fixed effects that control for permanent regional differences in labor market conditions. Hence, our result is not driven by permanent regional differences that affect the unemployment rate and the wage sweep-up simultaneously. In the third column, we add year fixed effects. The point estimate of $b$ is again significant and positive. The size and the standard error of $b$ is now higher. That $b$ remains positive and significant means that the estimate of $b$ is not just driven by year effects that affect the wage sweep-up and the unemployment rate simultaneously. In fact, as can be seen from the $R^{2}$ in the third column, the year fixed effects do not add much to the explanation of unemployment, once one controls for the wage sweep-up. They mainly blow up the standard error of the estimate. The two point estimates of $b$ in the first and third column are therefore not significantly different. In our

\footnotetext{
${ }^{16}$ Remember (from section 6.1) that the level of the unemployment rate does not affect notional wage changes. Instead, notional changes are affected by labor market experience, tenure, unemployment growth, age, etc. The differences in these variables across cantons and industries determine, together with our estimate of $\mu_{c}$ and $\sigma_{c}$, the different wage sweep-ups in cantons and industries. Note also that the correlation between cantonal (industry) unemployment rates and cantonal (industry) unemployment growth is negligible (-0.01 for the cantons and 0.13 for the industries). Hence, the cantonal (industry) wage sweep-ups can be used as an independent variable in the explanation of cantonal (industry) unemployment rates.

${ }^{17}$ For the other cantons we have too few data to get useful estimates. In total we lose less than 2 percent of all observations by excluding the small cantons.
} 
strictest specification, in the fourth column, we add year and cantonal fixed effects to the regression and find that the point estimate of $b$ is still positive and highly significant.

In Figure $6 \mathrm{~b}$ we plotted the relation between unemployment rate and wage sweep-up for each industry. Again the same picture emerges. In almost every industry the increase in the wage sweep-up is associated with an increase in the unemployment rate. Interestingly, however, the steepness of this relation varies considerably across industries. While, e.g., the relation is very steep in tourism and construction, it is less steep in the banking and the insurance sector. Analogously to the regression for the cantons above we also conducted a regression for the industries. Panel B of Table 6 reports the result of this regression. In all specifications the wage sweep up has a sizeable and significant impact on industry unemployment. Interestingly, the size of $b$ in Panel B is quantitatively quite similar to the estimated size of $b$ in Panel A.

Thus, Figures $6 \mathrm{a}$ and $6 \mathrm{~b}$ and the results in Table 6 show that variations in unemployment rates across cantons and industries are strongly related to the corresponding variations in wage sweep-ups caused by nominal rigidity. This represents strong evidence that in the low growthlow inflation environment, which characterized the Swiss economy in the 1990s nominal wage rigidity had negative employment effects.

\section{Concluding Remarks}

It has been argued that in a macro-environment with persistently low nominal GDP growth the downward rigidity of nominal wages will vanish. Workers will become accustomed to more frequent nominal wage cuts and employers will, therefore, not shy away from cutting nominal pay. If this argument is valid nominal wage rigidity would be largely irrelevant because in an environment with high nominal growth rates there is little need to cut nominal pay to achieve real wage adjustments while in a low-growth environment nominal rigidity would be absent.

This paper uses three different data sources to examine this conjecture for the Swiss situation between 1991 and 1997. During this time Switzerland went through a unique macro economic phase with negative or very low real GDP growth and a rapidly declining rate of inflation. All three data sources used in our paper show that nominal wage rigidity also persists in periods of low nominal growth. According to the personnel files of two firms wage cuts almost never occur. The data from the Swiss Labor Force Survey indicate that at most 8 percent of the job stayers receive wage cuts while nominal rigidity prevents wage cuts for 50 or more percent of 
the job stayers. The data from the Social Insurance Files suggest even fewer wage cuts. Our estimates also show that the impact of nominal rigidity does not decline in this period of sustained low nominal GDP growth. While there was a tiny increase in the fraction of employees willing to take wage cuts, this increase was far too small to accommodate the greater need for wage cuts. The fraction of workers whose wages are not cut because of nominal rigidity increases considerably over time while the frequency of true wage cuts is roughly constant. This indicates that, although the downward pressure on nominal wages increased over time, the downward rigidity of nominal wages remained a binding constraint for many employees. Moreover, the relatively large coefficient on the unemployment change in our wage growth equation suggests that in the absence of nominal rigidity wages would be quite flexible.

Theories of nominal wage rigidity that are based on the existence of efficient nominal contracts or on nominal fairness standards in repeated work relations predict that the wages of job movers show less rigidity than the wages of job stayers. These theories also suggest that the wages of part-time workers exhibit less rigidity than the wages of full-time workers. Our results confirm these predictions and lend thus support to these theories.

Our examination also suggests that nominal wage rigidity has important macroeconomic effects in an environment with low real growth and low inflation. The wage sweep-up due to nominally rigid wages explains a large part of the variations in the rate of unemployment across industries and across cantons: The higher the wage sweep-up the higher is the unemployment rate. This lends support to the view that the downward rigidity of nominal wages is sufficiently strong to cause an increase in real labor costs and a decrease in employment. 


\section{References}

Agell, Jonas and Per Lundborg (1995), Theories of Pay and Unemployment: Survey Evidence from Swedish Manufacturing Firms, Scandinavian Journal of Economics 97, 295-307.

Akerlof, George, William Dickens and George Perry (1996), The Macroeconomics of Low Inflation, Brookings Papers on Economic Activity (1), 1 - 52.

Altonji, Joseph G. and Paul J. Devereux (1999), The Extent and Consequences of Downward Nominal Wage Rigidity, NBER Working Paper \# 7236.

Angrist, Joshua and Alan Krueger (1999), Empirical Strategies in Labor Economics, forthcoming in: Handbook of Labor Economics vol. 5.

Baker, George, Michael Gibbs and Bengt Holmström (1994), The Wage Policy of a Firm, Quarterly Journal of Economics 109(4), pp. 921-955.

Bewley, Truman E. (1999), Why Wages Don't Fall During a Recession, Cambridge: Harvard University Press.

Blinder, Alan and Don H. Choi (1990), A Shred of Evidence of Theories of Wage Stickiness, Quarterly Journal of Economics 105(3), 1003 - 1015.

Campbell, Carl and Kunal Kamlani (1997), The Reasons for Wage Rigidity: Evidence from a Survey of Firms, Quarterly Journal of Economics 112(3), 759-89.

Card, David and Dean Hyslop (1996), Does Inflation „Grease the Wheels“ of the Labor Market?, NBER Working Paper No. 5538.

Fehr, Ernst and Armin Falk (1999), Wage Rigidity in a Competitive Incomplete Contract Market, Journal of Political Economy 107, 106-134.

Fehr, Ernst and Simon Gächter (2000), Fairness and Retaliation - The Economics of Reciprocity, Journal of Economic Perspectives 14, 159-181.

Genesove, David and Christopher J. Mayer (1998), Loss Aversion and Seller Behavior: Evidence form the Housing Market, mimeo

Gordon, Robert J. (1996), Comment and Discussion: Akerlof et al.: The Macroeconomics of Low Inflation, Brookings Papers on Economic Activity (1), 66 - 78.

Holden, Steinar (1999), Renegotiation and the Efficiency of Investments, Rand Journal of Economics 30, pp. 106-119.

Kahn, Shulamit. (1997), Evidence of Nominal Wage Stickiness from Microdata, American Economic Review 87(5), pp. 993-1008 
Kahneman, Daniel and Amos Tversky (1979), Prospect Theory: An Analysis of Decision under Risk, Econometrica 47(2), pp. 263 - 291.

Kahneman, Daniel, Jack Knetsch and Richard Thaler (1986), Fairness as a Constraint on Profit Seeking: Entitlement in the Market, American Economic Review 76(4), pp. 728 741.

Lebow, David, David Stockton and William Washer (1995), Inflation, Nominal Wage Rigidity, and the Efficiency of Labor Markets, Board of Governors of the Federal Reserve System, Finance and Economics Discussion Series.

Lebow, David, Raven Saks and Beth Anne Wilson (1999), Downward Nominal Wage Rigidity: Evidence from the Employment Cost Index, Board of Governors of the Federal Reserve System, Finance and Economics Discussion Series.

MacLeod, Bentley and James Malcolmson (1989), Implicit Contracts, Incentive Compatibility, and Involuntary Unemployment", Econometrica, 57(1), pp. 312-322.

MacLeod, Bentley and James M. Malcomson (1993), Investments, Hold-up and the Form of Market Contracts, American Economic Review 83(4), pp. 811 - 837.

Mankiw, N. Gregory (1996), Comment and Discussion: Akerlof et al.: The Macroeconomics of Low Inflation, Brookings Papers on Economic Activity (1), 66 - 78.

McLaughlin, Kenneth (1994), Rigid Wages?, Journal of Monetary Economics, 34, pp. 383 414.

Shafir, Eldar, Diamond, Peter and Amos Tversky (1997): On Money Illusion. Quarterly Journal of Economics, 112(May): 341-74.

Smith, Jennifer (1999), Nominal Wage Rigidities: Evidence from the UK, unpublished manuscript, University of Warwick.

Topel, Robert (1991), Specific Capital, Mobility, and Wages: Wages Rise with Job Seniority, Journal of Political Economy 99(1), pp. 145-176.

Wilson, Beth Anne (1999), Wage Rigidity: A Look Inside the Firm, Board of Governors of the Federal Reserve System, Finance and Economics Discussion Series.

Winter-Ebmer, Rudolf and Josef Zweimüller (1999); Firm-Size Wage Differentials in Switzerland: Evidence from Job-Changers, American Economic Review 89(2), pp. 8993. 
TABle A1: Robustness CHeCKS SIF SAMPLE - ML EstimateS

\begin{tabular}{|c|c|c|c|c|c|c|}
\hline & \multicolumn{3}{|c|}{$\begin{array}{l}\text { SOCIAL INSURANCE FILES } \\
\text { CANTONAL SAMPLE }^{\mathrm{C}}\end{array}$} & \multicolumn{3}{|c|}{$\begin{array}{l}\text { SOCIAL INSURANCE FILES } \\
\text { INDUSTRY SAMPLE }^{C}\end{array}$} \\
\hline & (1) & (2) & (3) & (1) & (2) & (3) \\
\hline $\begin{array}{l}\text { Mean Threshold of } \\
\text { cutting wages } \mu_{c}\end{array}$ & $\begin{array}{l}\mathbf{0 . 3 8 3 * *} \\
(\mathbf{0 . 0 1 )}\end{array}$ & $\begin{array}{l}0.393 * * \\
(\mathbf{0 . 0 1})\end{array}$ & $\begin{array}{l}\text { 1.118** } \\
(0.068)\end{array}$ & $\begin{array}{l}0.373 * * \\
(0.011)\end{array}$ & $\begin{array}{l}0.376 * * \\
(0.012)\end{array}$ & $\begin{array}{l}0.908 * * \\
(0.045)\end{array}$ \\
\hline $\begin{array}{l}\text { Standard Deviation } \sigma_{c} \\
\text { (Conditional Standard } \\
\text { Deviation when } \rho_{e c} \neq 0 \text { ) }\end{array}$ & $\begin{array}{l}\mathbf{0 . 2 1} * * \\
(\mathbf{0 . 0 1})\end{array}$ & $\begin{array}{l}0.22 * * \\
(0.01)\end{array}$ & $\begin{array}{l}0.544 \\
(0.035)\end{array}$ & $\begin{array}{l}0.195 * * \\
(0.012)\end{array}$ & $\begin{array}{l}0.196 * * \\
(0.012)\end{array}$ & $\begin{array}{l}0.401 * * \\
(0.031)\end{array}$ \\
\hline $\begin{array}{l}\text { Correlation with } \\
\text { idiosyncratic wage } \\
\text { change } e_{i t}: \rho_{e c}\end{array}$ & Zero & Zero & $\begin{array}{l}0.541 * * \\
(0.068)\end{array}$ & Zero & Zero & $\begin{array}{l}0.529 * * \\
(0.055)\end{array}$ \\
\hline $\begin{array}{l}\text { Implied Frequency of } \\
\text { Nominal Wage Cuts }\end{array}$ & 0.071 & 0.071 & 0.06 & 0.06 & 0.06 & 0.051 \\
\hline $\begin{array}{l}\text { Fraction of Workers } \\
\text { affected by Nominal } \\
\text { Wage Rigidities } \\
\end{array}$ & 0.542 & 0.542 & 0.499 & 0.536 & 0.537 & 0.497 \\
\hline $\begin{array}{l}\text { Change in regional / } \\
\text { industry Unemployment } \\
\text { Rate }\end{array}$ & $\begin{array}{l}-.008 * * \\
(0.002)\end{array}$ & $\begin{array}{l}-.009 * * \\
(0.002)\end{array}$ & $\begin{array}{l}-.009 * \\
(0.002)\end{array}$ & $\begin{array}{l}-.01 * * \\
(0.001)\end{array}$ & $\begin{array}{l}-.01 * * \\
(0.001)\end{array}$ & $\begin{array}{l}-.009 * * \\
(0.001)\end{array}$ \\
\hline $\log ($ Age $)$ & $\begin{array}{l}-1.15 * * \\
(0.06)\end{array}$ & $\begin{array}{l}-1.55^{* *} \\
(0.09)\end{array}$ & $\begin{array}{l}-1.64 * * \\
(0.088)\end{array}$ & $\begin{array}{l}-1.63 * * \\
(0.053)\end{array}$ & $\begin{array}{l}-1.96 * * \\
(0.073)\end{array}$ & $\begin{array}{l}-2.08 * * \\
(0.075)\end{array}$ \\
\hline $\log ^{2}($ Age $)$ & $\begin{array}{l}0.146 * * \\
(0.008)\end{array}$ & $\begin{array}{l}0.197 * * \\
(0.01)\end{array}$ & $\begin{array}{l}0.208 * * \\
(0.012)\end{array}$ & $\begin{array}{l}0.209 * * \\
(0.007)\end{array}$ & $\begin{array}{l}0.253 * * \\
(0.01)\end{array}$ & $\begin{array}{l}0.269 * * \\
(0.01)\end{array}$ \\
\hline $\begin{array}{l}\text { Foreigner (dummy } \\
\text { variable) }\end{array}$ & $\begin{array}{l}-0.07 * * \\
(0.021)\end{array}$ & $\begin{array}{l}-.488^{*} \\
(0.249)\end{array}$ & $\begin{array}{l}-0.49 * \\
(0.253)\end{array}$ & $\begin{array}{l}-0.1 * * \\
(0.018)\end{array}$ & $\begin{array}{l}-0.70 * * \\
(0.218)\end{array}$ & $\begin{array}{l}-0.73 * * \\
(0.22)\end{array}$ \\
\hline Female (dummy variable) & -- & $\begin{array}{l}-1.27 * * \\
(0.214)\end{array}$ & $\begin{array}{l}-1.33 * * \\
(0.215)\end{array}$ & -- & $\begin{array}{l}-1.08 * * \\
(0.2)\end{array}$ & $\begin{array}{l}-1.23 * * \\
(0.201)\end{array}$ \\
\hline Foreign $\times \log ($ Age $)$ & $\begin{array}{l}0.019 * * \\
(0.006)\end{array}$ & $\begin{array}{l}0.247 \\
(0.138)\end{array}$ & $\begin{array}{l}0.249 * * \\
(0.141)\end{array}$ & -- & $\begin{array}{l}0.361 * * \\
(0.121)\end{array}$ & $\begin{array}{l}0.378 * * \\
(0.123)\end{array}$ \\
\hline Foreigner $\times \log ^{2}($ Age $)$ & -- & $\begin{array}{l}-0.03 \\
(0.019)\end{array}$ & $\begin{array}{l}-0.03 \\
(0.02)\end{array}$ & -- & $\begin{array}{l}-.046 * * \\
(0.016)\end{array}$ & $\begin{array}{l}-.049 * * \\
(0.017)\end{array}$ \\
\hline
\end{tabular}

CONTINUED ON NEXT PAGE $\rightarrow$ 
TABLE A1, CONT.

\begin{tabular}{|c|c|c|c|c|c|c|}
\hline Female $\times \log ($ Age $)$ & -- & $\begin{array}{l}0.642 * * \\
(0.119)\end{array}$ & $\begin{array}{l}0.676^{* *} \\
(0.12)\end{array}$ & -- & $\begin{array}{l}0.54 * * \\
(0.112)\end{array}$ & $\begin{array}{l}0.616 * * \\
(0.113)\end{array}$ \\
\hline Female $\times \log ^{2}($ Age $)$ & -- & $\begin{array}{l}-.079 * * \\
(0.017)\end{array}$ & $\begin{array}{l}-.083 * * \\
(0.016)\end{array}$ & -- & $\begin{array}{l}-0.07 * * \\
(0.016)\end{array}$ & $\begin{array}{l}-0.08 * * \\
(0.016)\end{array}$ \\
\hline$\sigma_{e}$ & 0.115 & 0.129 & 0.127 & 0.125 & 0.124 & 0.121 \\
\hline$\sigma_{m}$ & 0.033 & 0.033 & 0.034 & 0.033 & 0.033 & 0.034 \\
\hline$P$ & 0.344 & 0.363 & 0.371 & 0.272 & 0.281 & 0.279 \\
\hline Year Effects & Yes & Yes & Yes & Yes & Yes & Yes \\
\hline $\begin{array}{l}\text { Number of } \\
\text { Observations }\end{array}$ & 58,297 & 58,297 & 58,297 & 55,884 & 55,884 & 55,884 \\
\hline Log likelihood & 44,770 & 44,907 & 45,103 & 49,433 & 49,552 & 49,706 \\
\hline
\end{tabular}

Notes: a. standard errors in parenthesis, adjusted for clustering on cantons and years. *,** denotes significance at the 5 percent and 1 percent level respectively.

b. $\sigma_{e}$ and $\sigma_{m}$ denote the standard deviation of $e_{i t}$ and $m_{i t}$, respectively.

c. Some agencies only enroll individuals from a particular canton. Individuals enrolled in these agencies form the 'cantonal' sample $(\mathrm{N}=58,297)$. Other agencies only enroll employees from a particular industry (the 'industry' sample, $\mathrm{N}=55,884$ ). 
YEARS

CONSIDERED
Median Number of CONSECUTIVE Years BELOW

\subsection{PERCENT ${ }^{\mathrm{a}}$ 2.6 PerCENT}

A. Previous Studies (United States)

$\begin{array}{lcccr}\text { Card and Hyslop (1996) } & 1976-1991 & 8.1 \% & 0 & 0 \\ \text { McLaughlin (1994) } & 1976-1986 & 11.3 \% & 0 & 0 \\ \text { Kahn (1997) } & 1971-1988 & 8.9 \% & 0 & 0 \\ \text { Akerlof, Dickens, and Perry (1996) } & 1959-1995 & 7.6 \% & 2 & 0 \\ \text { Altonji and Devereux (1999) } & 1972-1992 & 7.7 \% & 0 & 0 \\ \text { Lebow, Saks and Wilson (1999) } & 1981-1998 & 5.7 \% & 0 & 0\end{array}$

B. THIS STUDY (SWITZERLAND)

$1991-1997 \quad 2.2 \%$

All Years

6

Sources: Economic Report of the President 2000, Table B-3; Swiss National Bank Monthly Bulletin; own calculations.

Notes: a. The highest nominal GDP growth rate in Switzerland was 5.2 percent in 1991. 
TABLE 2: Descriptive Statistics of Wage FreEzes AND Wage Cuts

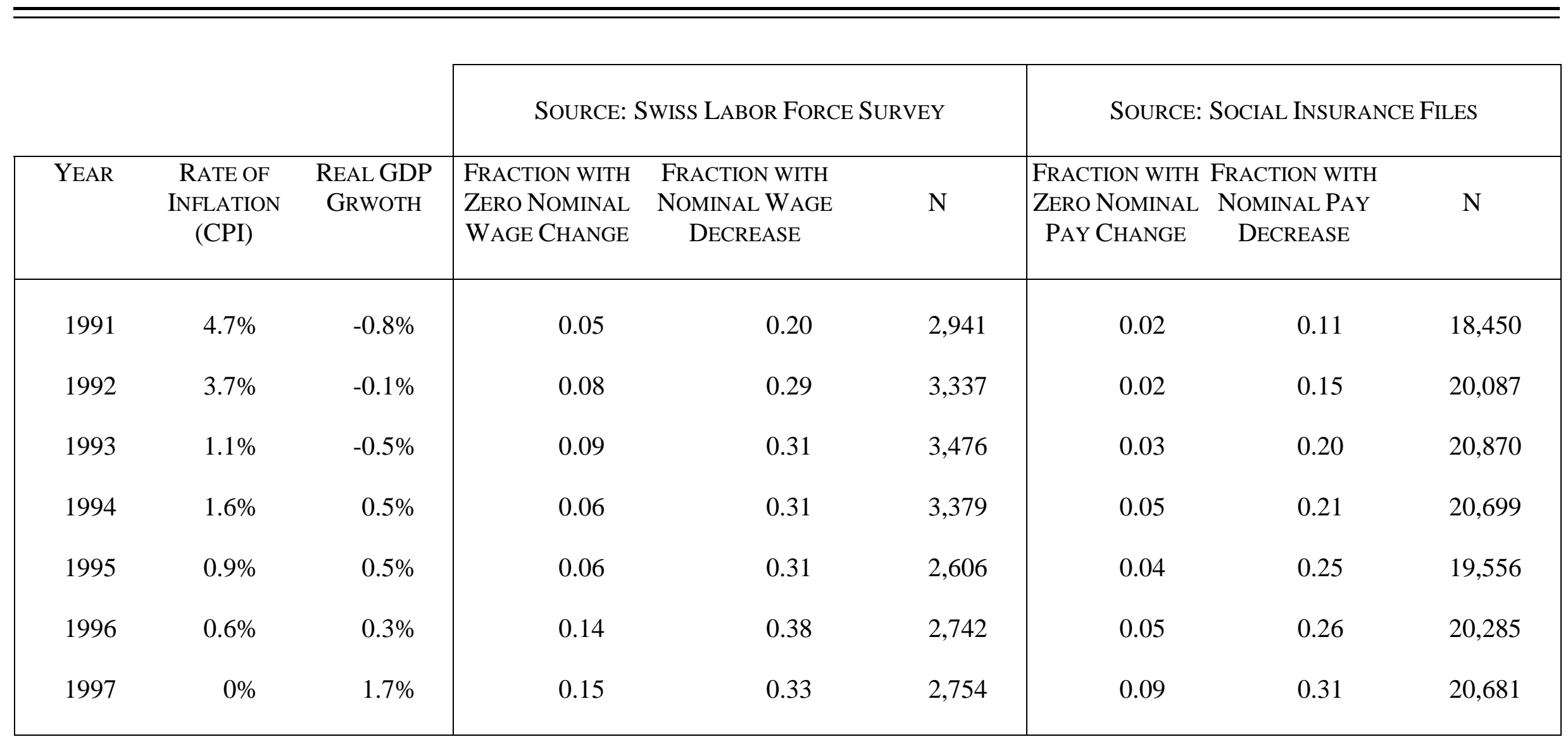

Sources: Federal Office of Statistics, Swiss Labour Force Survey 1991 - 1998, Social Insurance Files 1990 - 1997; own calculations. 
TAble 3: The Extent of Nominal Wage Rigidities - ML estimates

\begin{tabular}{|c|c|c|c|c|c|c|}
\hline & \multicolumn{3}{|c|}{ SWISS LABOR FORCE SURVEY } & \multicolumn{3}{|c|}{ SOCIAL INSURANCE FILES } \\
\hline & (1) & (2) & (3) & (1) & (2) & (3) \\
\hline $\begin{array}{l}\text { Mean Threshold for } \\
\text { wage cuts } \mu_{c}\end{array}$ & $\begin{array}{l}.268 * * \\
(.006)\end{array}$ & $\begin{array}{l}0.513 * * \\
(0.06)\end{array}$ & $\begin{array}{l}12.01 * \\
(5.34)\end{array}$ & $\begin{array}{l}.208 * * \\
(.002)\end{array}$ & $\begin{array}{l}0.383 * * \\
(0.01)\end{array}$ & $\begin{array}{l}\mathbf{0 . 8 9} * * \\
(0.03)\end{array}$ \\
\hline $\begin{array}{l}\text { Standard Deviation } \sigma_{c} \\
\text { (Conditional Standard } \\
\text { Deviation when } o \neq 0 \text { ) }\end{array}$ & Zero $^{c}$ & $\begin{array}{l}0.358 * * \\
(\mathbf{0 . 0 4})\end{array}$ & $\begin{array}{l}7.19 * \\
(3.14)\end{array}$ & Zero $^{c}$ & $\begin{array}{l}0.21 * * \\
(0.01)\end{array}$ & $\begin{array}{l}0.441 * * \\
(0.025)\end{array}$ \\
\hline $\begin{array}{l}\text { Correlation of } c_{i t} \text { with } \\
\text { idiosyncratic wage } \\
\text { change } e_{i t}: \rho_{e c}\end{array}$ & Zero $^{\mathrm{d}}$ & Zero $^{\mathrm{d}}$ & $\begin{array}{l}0.52 * * \\
(0.074)\end{array}$ & Zero $^{\mathrm{d}}$ & Zero $^{d}$ & $\begin{array}{l}0.48 * * \\
(0.025)\end{array}$ \\
\hline $\begin{array}{l}\text { Implied Frequency of } \\
\text { Nominal Wage Cuts }\end{array}$ & 0.023 & 0.08 & 0.069 & 0.047 & 0.071 & 0.063 \\
\hline $\begin{array}{l}\text { Share of Workers } \\
\text { affected by Nominal } \\
\text { Wage Rigidities }\end{array}$ & 0.556 & 0.522 & 0.483 & 0.48 & 0.542 & 0.494 \\
\hline Log Experience & $\begin{array}{l}-.012 * * \\
(.002)\end{array}$ & $\begin{array}{l}-.017 * * \\
(0.002)\end{array}$ & $\begin{array}{l}-.02 * * \\
(0.002)\end{array}$ & - & - & - \\
\hline Log Tenure & $\begin{array}{l}-.005 * * \\
(.002)\end{array}$ & $\begin{array}{l}-0.004 * \\
(0.002)\end{array}$ & $\begin{array}{l}-0.004 * \\
(0.002)\end{array}$ & - & - & - \\
\hline $\begin{array}{l}\text { Individual has } \\
\text { subordinates } \\
\text { (dummy variable) }\end{array}$ & $\begin{array}{l}.029 * * \\
(.006)\end{array}$ & $\begin{array}{l}0.031 * * \\
(0.007)\end{array}$ & $\begin{array}{l}0.032 * * \\
(0.007)\end{array}$ & - & - & - \\
\hline $\begin{array}{l}\text { Individual is member } \\
\text { of higher management } \\
\text { (dummy variable) }\end{array}$ & $\begin{array}{l}-.01 * * \\
(.003)\end{array}$ & $\begin{array}{l}-.011 * * \\
(0.003)\end{array}$ & $\begin{array}{l}-.013 * * \\
(0.004)\end{array}$ & - & - & - \\
\hline $\begin{array}{l}\text { Change in regional } \\
\text { Unemployment Rate }\end{array}$ & $\begin{array}{l}-.007 * \\
(.004)\end{array}$ & $\begin{array}{l}-.007 * \\
(0.003)\end{array}$ & $\begin{array}{l}-.0082 * \\
(0.004)\end{array}$ & $\begin{array}{l}-.008 * * \\
(.003)\end{array}$ & $\begin{array}{l}-.008 * * \\
(0.002)\end{array}$ & $\begin{array}{l}-.008 * * \\
(0.002)\end{array}$ \\
\hline Log(Age $)$ & - & - & - & $\begin{array}{l}-1.12 * * \\
(0.05)\end{array}$ & $\begin{array}{l}-1.15 * * \\
(0.06)\end{array}$ & $\begin{array}{l}-1.21 * * \\
(0.06)\end{array}$ \\
\hline
\end{tabular}


Table 3, Cont.

\begin{tabular}{|c|c|c|c|c|c|c|}
\hline $\log ^{2}$ (Age) & - & - & - & $\begin{array}{l}0.132 * * \\
(0.007)\end{array}$ & $\begin{array}{l}0.146 * * \\
(0.008)\end{array}$ & $\begin{array}{l}0.154 * * \\
(0.008)\end{array}$ \\
\hline $\begin{array}{l}\text { Foreigner (dummy } \\
\text { variable) }\end{array}$ & - & - & - & & $\begin{array}{l}-0.07 * * \\
(0.021)\end{array}$ & $\begin{array}{l}-0.07 * * \\
(0.021)\end{array}$ \\
\hline Foreigner*Log(Age) & - & - & - & & $\begin{array}{l}0.019 * * \\
(0.006)\end{array}$ & $\begin{array}{l}0.018 * * \\
(0.006)\end{array}$ \\
\hline$\sigma_{e}$ & 0.121 & 0.118 & 0.137 & 0.113 & 0.115 & 0.139 \\
\hline$\sigma_{m}$ & 0.073 & 0.058 & 0.061 & 0.041 & 0.033 & 0.033 \\
\hline$p$ & 0.394 & 0.424 & 0.418 & 0.33 & 0.344 & 0.341 \\
\hline Year Effects & Yes & Yes & Yes & Yes & Yes & Yes \\
\hline Firm-Size Effect & Yes & Yes & Yes & - & - & - \\
\hline $\begin{array}{l}\text { Number of } \\
\text { Observations }\end{array}$ & 21,144 & 21,144 & 21,144 & 58,297 & 58,297 & 58,297 \\
\hline Log likelihood & 8,330 & 8,513 & 8,530 & 43,221 & 44,770 & 44,904 \\
\hline
\end{tabular}

Notes: a. standard errors in parenthesis, adjusted for clustering on cantons and years. *, ** denotes significance at the 5 percent and 1 percent level respectively.

b. $\sigma_{e}$ and $\sigma_{m}$ denote the standard deviation of $e_{i t}$ and $m_{i t}$, respectively.

c. Model with $\sigma_{c}=0$ corresponds to the model estimated in Altonji and Devereux (1999).

d. Correlation of $c_{i t}$ with idiosyncratic wage change $e_{i t}$ is restricted to zero. 
TABle 4: THRESHOLD WAge CUT OVER TIME

ML ESTIMATES

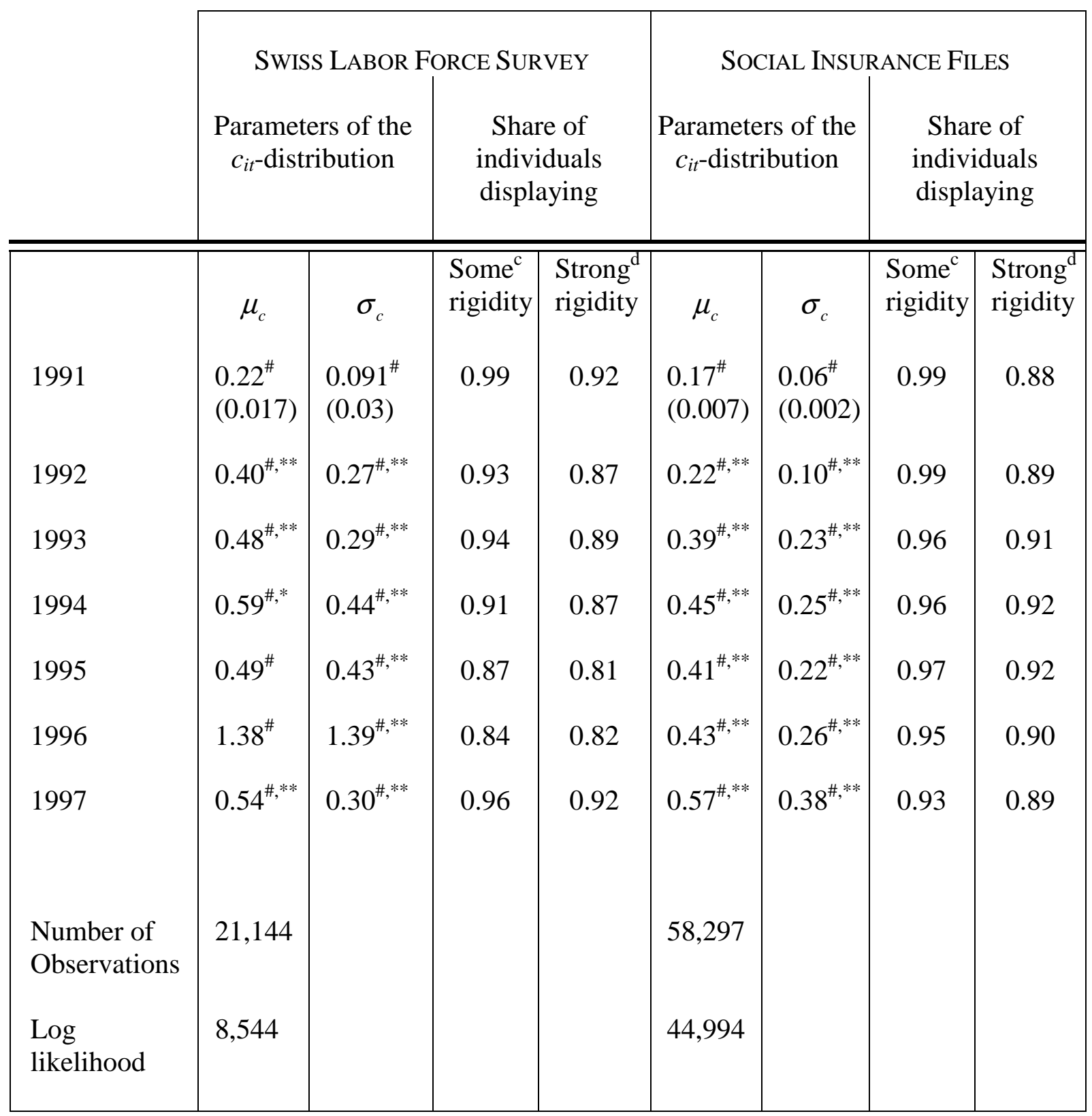

Notes: a. standard errors for 1991 are in parenthesis, adjusted for clustering on cantons and years. To preserve spaces, all standard errors except those for 1991 have been suppressed. " denotes significant difference from zero at the five percent level. ${ }^{*},{ }^{* *}$ denotes significant difference relative to the estimate in 1991 at the 5 percent and 1 percent level respectively.

b. Same specification as in Table 3, column (1).

c. Some rigidity is defined by a positive threshold for wage cuts $\left(c_{i t}>0\right)$.

d. Strong rigidity is defined by a threshold wage cut of $c_{i t}>0.1$. 
TABLE 5: NOMINAL RIGIDITIES FOR DIFFERENT GROUPS OF WORKERS

ML ESTIMATES FROM SWISS LABOR FORCE SURVEY, 1991 - 1997

\begin{tabular}{|c|c|c|c|c|}
\hline & \multicolumn{2}{|c|}{$\begin{array}{l}\text { FULL-TIME VS. } \\
\text { PART-TIME WORK }\end{array}$} & \multicolumn{2}{|c|}{$\begin{array}{c}\text { JOB STAYERS VS. } \\
\text { JOB MOVERS }\end{array}$} \\
\hline & $\begin{array}{l}\text { Full-Time } \\
\text { Job Stayers }\end{array}$ & $\begin{array}{l}\text { Part-Time } \\
\text { Job Stayers }\end{array}$ & Job Stayers & Job Movers \\
\hline $\begin{array}{l}\text { Mean Threshold for Wage } \\
\text { Cuts } \mu_{c}\end{array}$ & $\begin{array}{l}0.987 * * \\
(0.03)\end{array}$ & $\begin{array}{l}0.20 * * \\
(0.06)\end{array}$ & $\begin{array}{l}0.644 * * \\
(0.04)\end{array}$ & $\begin{array}{l}0.098 * * \\
(0.01)\end{array}$ \\
\hline $\begin{array}{l}\text { Standard Deviation of } \\
\text { Threshold Distribution } \sigma_{c}\end{array}$ & $\begin{array}{l}0.69 * * \\
(0.02)\end{array}$ & $\begin{array}{l}0.155^{* *} \\
(0.02)\end{array}$ & $\begin{array}{l}0.465 * * \\
(0.03)\end{array}$ & $\begin{array}{l}0.07 * * \\
(0.02)\end{array}$ \\
\hline $\begin{array}{l}\text { Share of Individuals } \\
\text { Displaying }\end{array}$ & & & & \\
\hline Some nominal rigidity ${ }^{\mathrm{c}}$ & 0.923 & 0.905 & 0.917 & 0.917 \\
\hline $\begin{array}{l}\text { Strong nominal rigidity } \\
\text { Frequency of Wage } \\
\text { Freezes and Wage Cuts }\end{array}$ & 0.901 & 0.748 & 0.879 & 0.487 \\
\hline Frequency of Wage Cuts & 0.068 & 0.155 & 0.084 & 0.206 \\
\hline $\begin{array}{l}\text { Frequency of Wage } \\
\text { Freezes }\end{array}$ & 0.572 & 0.48 & 0.552 & 0.406 \\
\hline$\sigma_{e}$ & 0.139 & & 0.145 & \\
\hline$\sigma_{m}$ & 0.058 & & 0.059 & \\
\hline Number of Observations & 21,144 & & 22,971 & \\
\hline Log likelihood & 8,513 & & 8,929 & \\
\hline
\end{tabular}

Notes: a. standard errors in parenthesis, adjusted for clustering on cantons and years. *,** denotes significance at the 5 percent and 1 percent level respectively.

b. Same specification as in Table 3, column (2).

c. Some rigidity is defined by a positive threshold wage cut $\left(c_{i t}>0\right)$.

d. Strong rigidity is defined by a threshold wage cut of $c_{i t}>0.1$. 
TABLE 6: The ReAl EFFECTS of DownWARd Nominal WAge Rigidity

OLS REGRESSIONS

DEPENDENT VARIABLE: UNEMPLOYMENT RATE, 1991 - 1997

\begin{tabular}{|l|l|l|c|c|}
\cline { 2 - 5 } \multicolumn{1}{c|}{} & \multicolumn{4}{c|}{ A. UnEMPLOYMENT ACROSS 17 LARGEST CANTONS } \\
\hline$E_{j t}\left(\Delta w-\Delta w^{*}\right)$ & $\begin{array}{l}1.17^{* * *} \\
(0.10)\end{array}$ & $\begin{array}{l}1.11^{* * *} \\
(0.09)\end{array}$ & $\begin{array}{l}2.24^{* * *} \\
(0.88)\end{array}$ & $\begin{array}{l}1.69^{* * *} \\
(0.44)\end{array}$ \\
\hline$R^{2}$ & 0.49 & 0.90 & 0.56 & 0.95 \\
Cantonal Fixed Effects & No & Yes & No & Yes \\
Year Fixed Effects & No & No & Yes & Yes \\
\hline
\end{tabular}

\begin{tabular}{|l|c|c|c|c|}
\cline { 2 - 5 } \multicolumn{1}{c|}{} & \multicolumn{4}{c|}{ B. UNEMPLOYMENT ACROSS 16 LARGEST INDUSTRIES } \\
\hline$E_{j t}\left(\Delta w-\Delta w^{*}\right)$ & $\begin{array}{l}0.98^{* * *} \\
(0.19)\end{array}$ & $\begin{array}{l}0.91^{* * *} \\
(0.17)\end{array}$ & $\begin{array}{l}1.90^{* * *} \\
(0.65)\end{array}$ & $\begin{array}{l}1.69^{* * *} \\
(0.56)\end{array}$ \\
\hline$R^{2}$ & 0.27 & 0.85 & 0.33 & 0.89 \\
Industry Fixed Effects & No & Yes & No & Yes \\
Year Fixed Effects & No & No & Yes & Yes \\
\hline
\end{tabular}

Notes: a) standard errors, adjusted for clustering on cantons or industry respectively, in parentheses.

b) $\quad * * *$ denotes significance at the 1 percent level.

c) $\quad \mathrm{N}=119$ canton and year cells in Panel $\mathrm{A}$, and $\mathrm{N}=112$ industry and year cells in Panel B. 


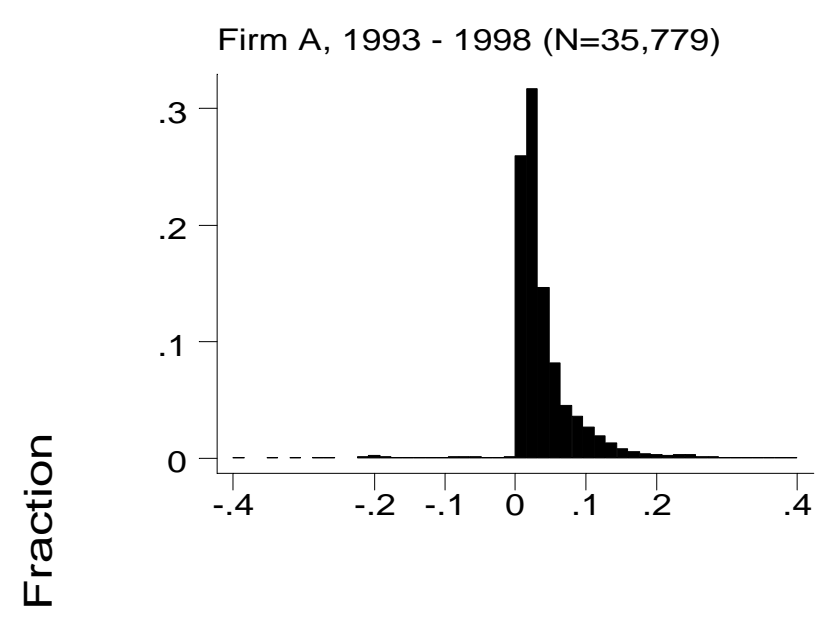

Firm B, 1984 - $1998(\mathrm{~N}=20,236)$

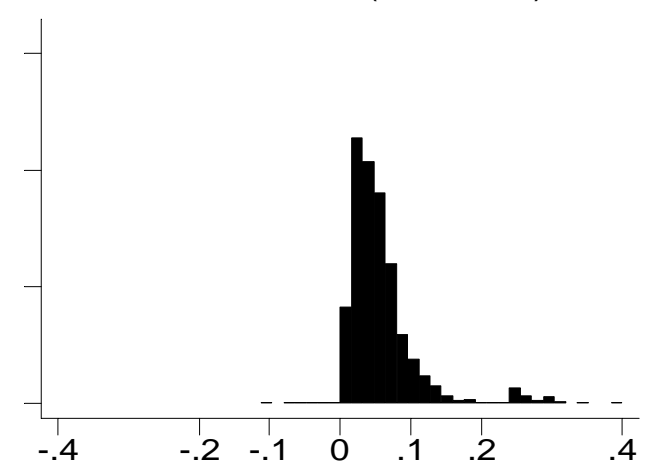

Evidence from Personnel Files

Figure 1: Distribution of Nominal Wage Changes 
Swiss Labor Force Survey $(\mathrm{N}=21,144)$

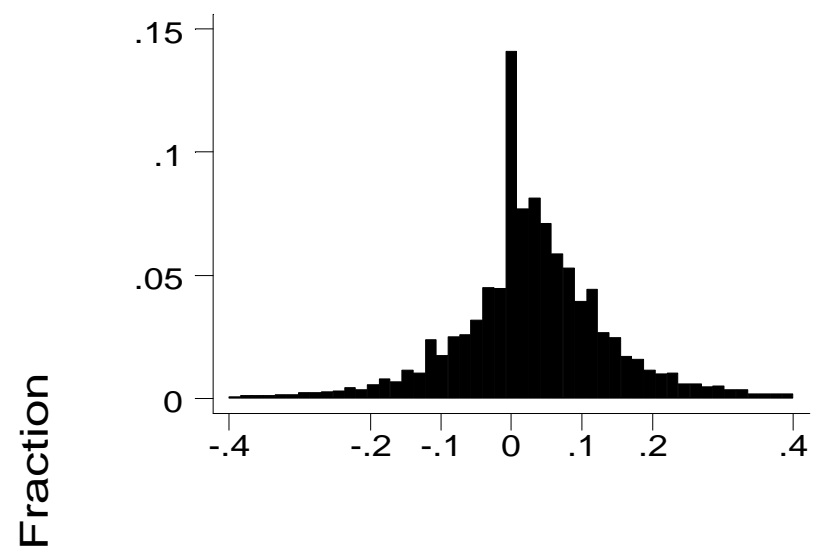

Social Insurance Files $(\mathrm{N}=140,628)$

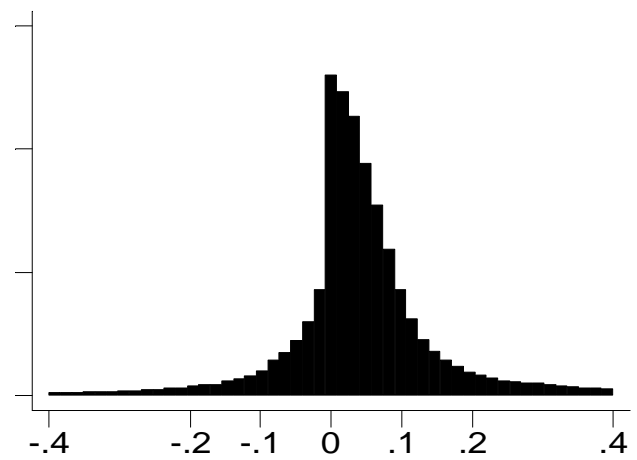

Evidence from Representative Samples, Switzerland 1991 - 1997 Figure 2: Distribution of Nominal Wage Changes 


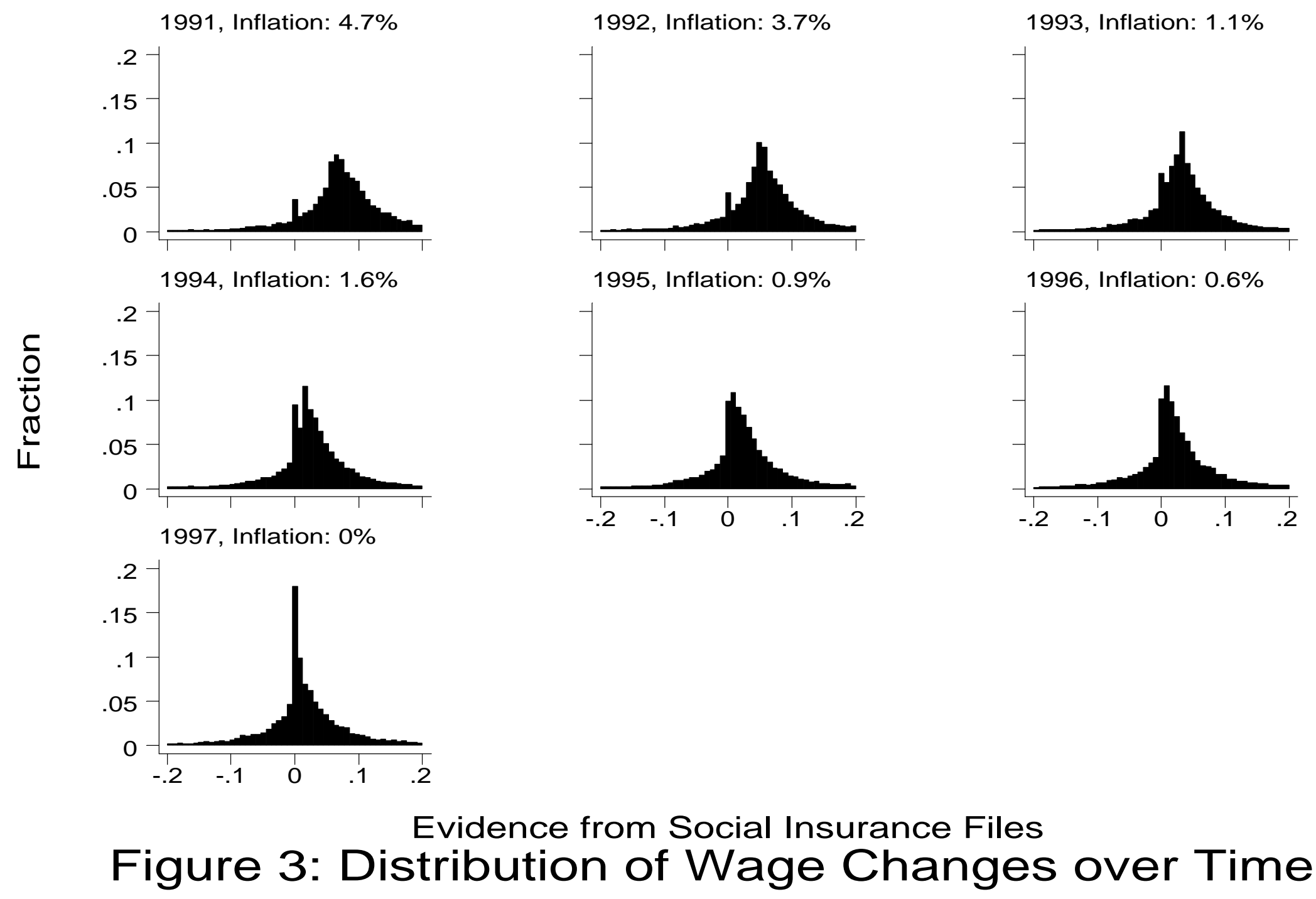



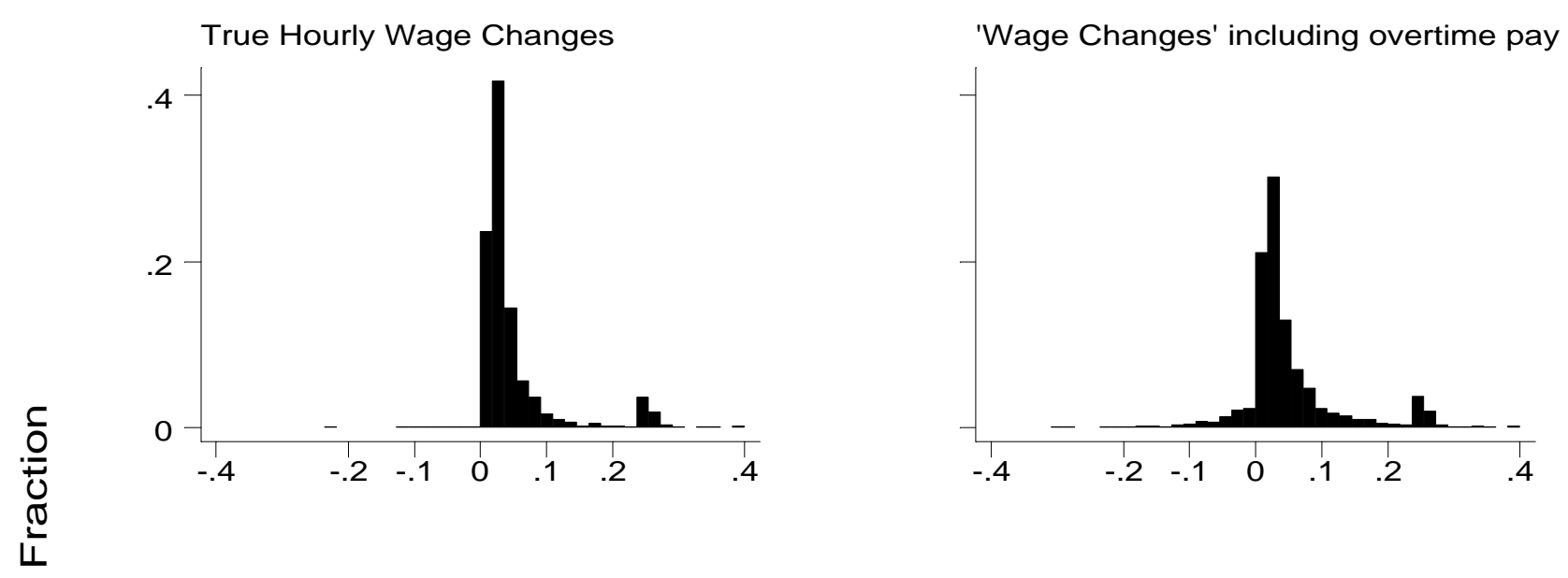

Evidence from Personnel Files, Firm B, 1993 - 1998 Figure 4: True and Polluted Wage Changes 
Panel (a): Inflation Rate and Resistance against Wage Cuts Estimates from SLFS

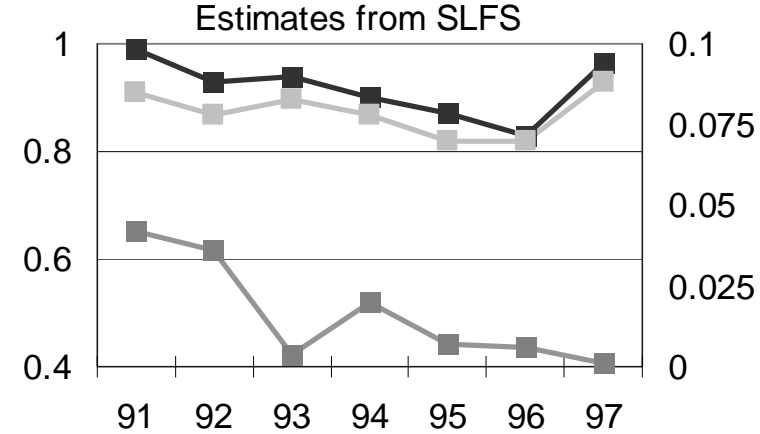

-Fraction with $\mathrm{c}>0 \quad-$ Fraction with $\mathrm{c}>.1$ - Inflation (May to May)

Panel (c): The Extent of Nominal Wage Rigidities over Time

Estimates from SLFS

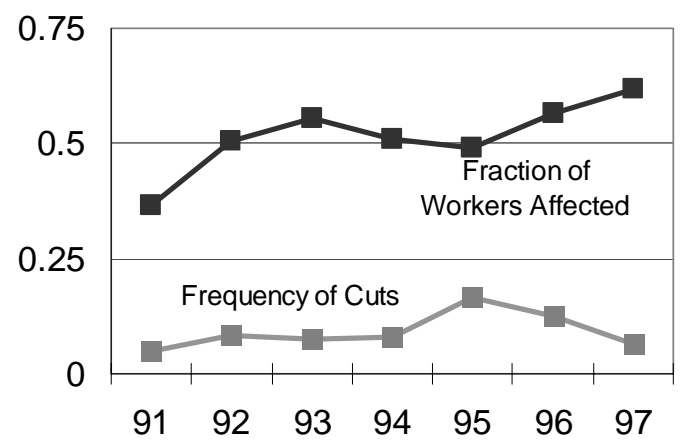

Panel (e): Average Prevented Real Wage Cut

Estimates from SLFS

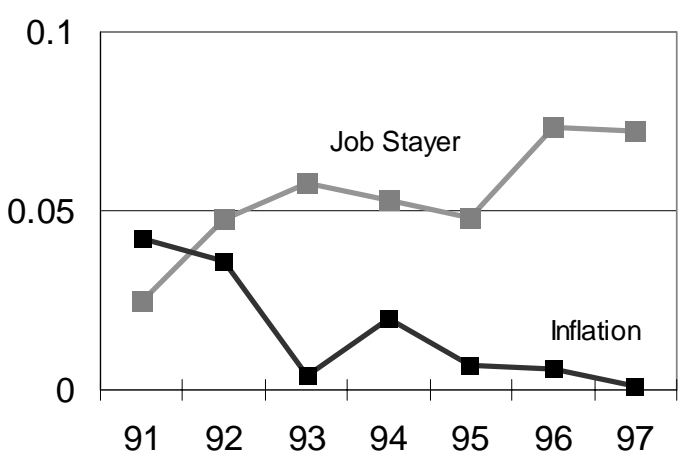

Panel (b): Inflation Rate and Resistance against Wage Cuts Estimates from SIF

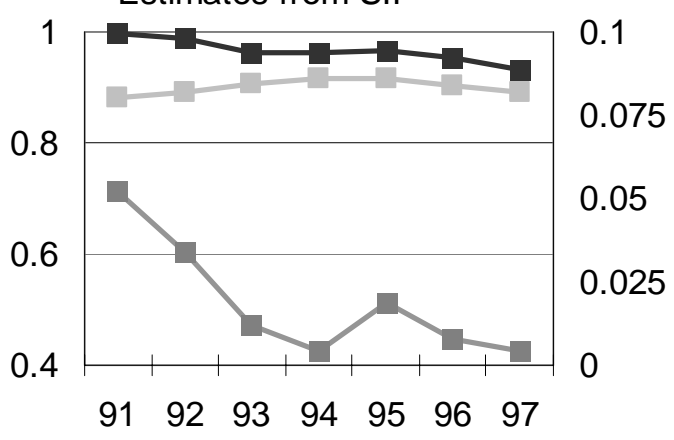

$\rightarrow$ Fraction with $\mathrm{c}>0 \quad-$ Fraction with $\mathrm{c}>.1$ Inflation (Dec to Dec)

Panel (d): The Extent of Nominal Wage Rigidities over Time

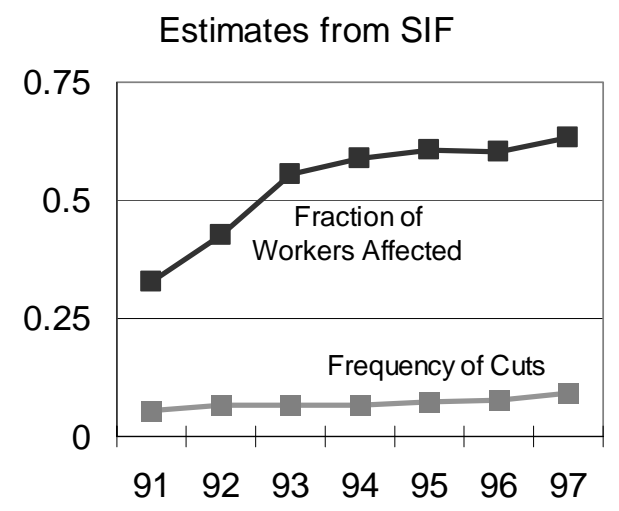

\section{Panel (f): Average Prevented Real Wage Cut}

Estimates from SIF

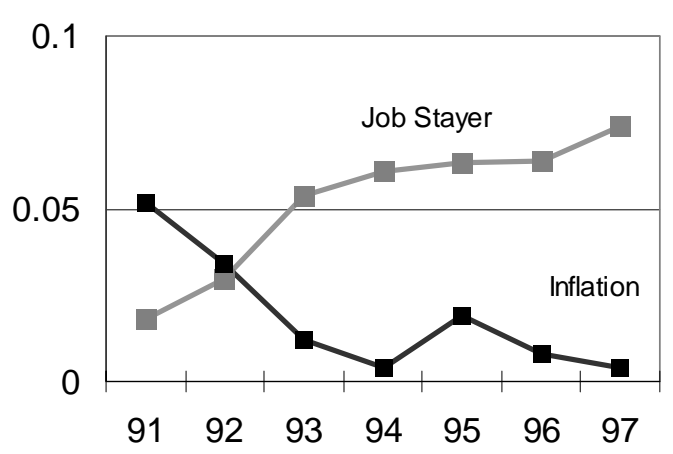

FigURE 5: ARE NOMINAL RigiditiES FADING? 


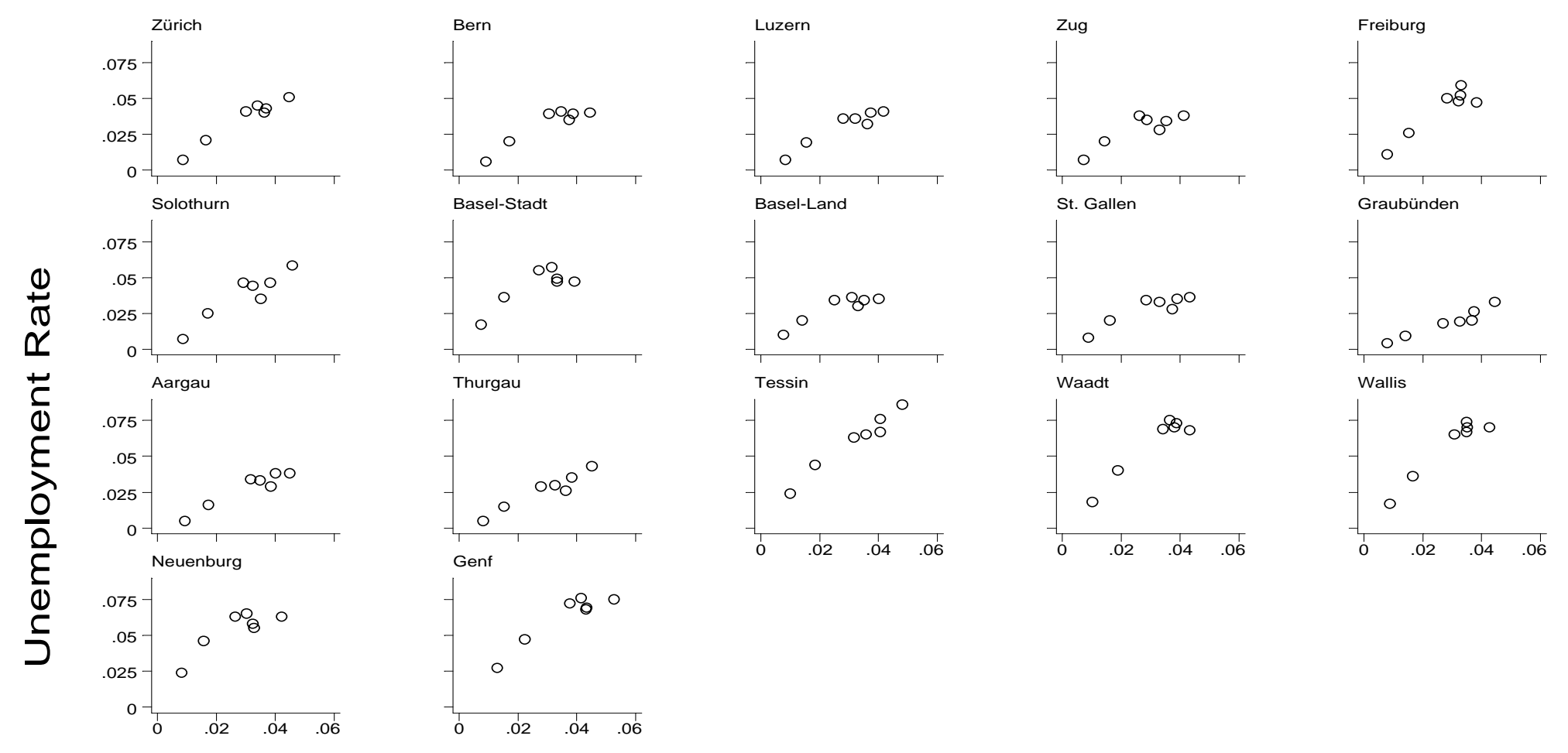

Figure 6a: Unemployment rate and Wage Sweep-Up across Cantons 

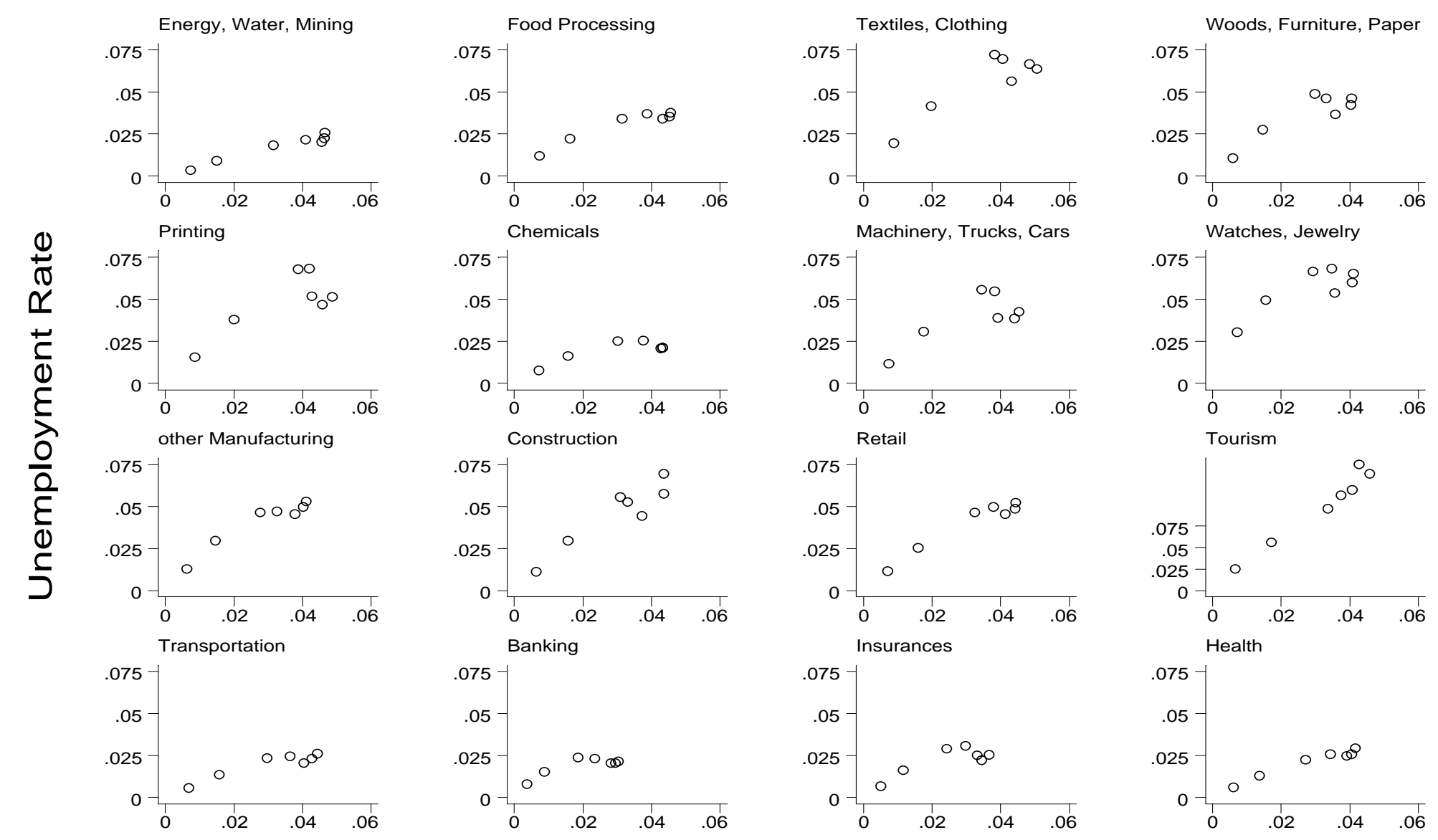

Figure 6b: Unemployment rate and Wage Sweep-Up across Industries 


\section{Working Papers of the Institute for Empirical Research in Economics}

No.

1. Rudolf Winter-Ebmer and Josef Zweimüller: Firm Size Wage Differentials in Switzerland: Evidence from Job Changers, February 1999

2. Bruno S. Frey and Marcel Kucher: History as Reflected in Capital Markets: The Case of World War II, February 1999

3. Josef Falkinger, Ernst Fehr, Simon Gächter and Rudolf Winter-Ebmer: A Simple Mechanism for the Efficient Provision of Public Goods - Experimental Evidence, February 1999

4. Ernst Fehr and Klaus M. Schmidt: A Theory of Fairness, Competition and Cooperation, April 1999

5. Markus Knell: Social Comparisons, Inequality, and Growth, April 1999

6. Armin Falk and Urs Fischbacher: A Theory of Reciprocity, July 2000

7. Bruno S. Frey and Lorenz Goette: Does Pay Motivate Volunteers?, May 1999

8. Rudolf Winter-Ebmer and Josef Zweimüller: Intra-firm Wage Dispersion and Firm Performance, May 1999

9. Josef Zweimüller: Schumpeterian Entrepreneurs Meet Engel's Law: The Impact of Inequality on InnovationDriven Growth, May 1999

10. Ernst Fehr and Simon Gächter: Cooperation and Punishment in Public Goods Experiments, June 1999

11. Rudolf Winter-Ebmer and Josef Zweimüller: Do Immigrants Displace Young Native Workers: The Austrian Experience, June 1999

12. Ernst Fehr and Jean-Robert Tyran: Does Money Illusion Matter?, June 1999

13. Stefan Felder and Reto Schleiniger: Environmental Tax Reform: Efficiency and Political Feasibility, July 1999

14. Bruno S. Frey: Art Fakes - What Fakes?, An Economic View, July 1999

15. Bruno S. Frey and Alois Stutzer: Happiness, Economy and Institutions, July 1999

16. Urs Fischbacher, Simon Gächter and Ernst Fehr: Are People Conditionally Cooperative? Evidence from a Public Goods Experiment, July 2000

17. Armin Falk, Ernst Fehr and Urs Fischbacher: On the Nature of Fair Behavior, August 1999

18. Vital Anderhub, Simon Gächter and Manfred Königstein: Efficient Contracting and Fair Play in a Simple Principal-Agent Experiment, September 2000

19. Simon Gächter and Armin Falk: Reputation or Reciprocity? Consequences for the Labour Relation, July 2001

20. Ernst Fehr and Klaus M. Schmidt: Fairness, Incentives, and Contractual Choices, September 1999

21. Urs Fischbacher: $z$-Tree - Experimenter's Manual, September 1999

22. Bruno S. Frey and Alois Stutzer: Maximising Happiness?, October 1999

23. Alois Stutzer: Demokratieindizes für die Kantone der Schweiz, October 1999

24. Bruno S. Frey: Was bewirkt die Volkswirtschaftslehre?, October 1999

25. Bruno S. Frey, Marcel Kucher and Alois Stutzer: Outcome, Process \& Power in Direct Democracy, November 1999

26. Bruno S. Frey and Reto Jegen: Motivation Crowding Theory: A Survey of Empirical Evidence, November 1999

27. Margit Osterloh and Bruno S. Frey: Motivation, Knowledge Transfer, and Organizational Forms, November 1999

28. Bruno S. Frey and Marcel Kucher: Managerial Power and Compensation, December 1999

29. Reto Schleiniger: Ecological Tax Reform with Exemptions for the Export Sector in a two Sector two Factor Model, December 1999

30. Jens-Ulrich Peter and Klaus Reiner Schenk-Hoppé: Business Cycle Phenomena in Overlapping Generations Economies with Stochastic Production, December 1999

31. Josef Zweimüller: Inequality, Redistribution, and Economic Growth, January 2000

32. Marc Oliver Bettzüge and Thorsten Hens: Financial Innovation, Communication and the Theory of the Firm, January 2000

33. Klaus Reiner Schenk-Hoppé: Is there a Golden Rule for the Stochastic Solow Growth Model? January 2000

34. Ernst Fehr and Simon Gächter: Do Incentive Contracts Undermine Voluntary Cooperation? April 2002

35. Marc Oliver Bettzüge and Thorsten Hens: An Evolutionary Approach to Financial Innovation, July 2000

36. Bruno S. Frey: Does Economics Have an Effect? Towards an Economics of Economics, February 2000

37. Josef Zweimüller and Rudolf Winter-Ebmer: Firm-Specific Training: Consequences for Job-Mobility, March 2000

The Working Papers of the Institute for Empirical Research in Economics can be downloaded in PDF-format from http://www.unizh.ch/iew/wp/ 


\section{Working Papers of the Institute for Empirical Research in Economics}

No.

38. Martin Brown, Armin Falk and Ernst Fehr: Contract Inforcement and the Evolution of Longrun Relations, March 2000

39. Thorsten Hens, Jörg Laitenberger and Andreas Löffler: On Uniqueness of Equilibria in the CAPM, July 2000

40. Ernst Fehr and Simon Gächter: Fairness and Retaliation: The Economics of Reciprocity, March 2000

41. Rafael Lalive, Jan C. van Ours and Josef Zweimüller: The Impact of Active Labor Market Programs and Benefit Entitlement Rules on the Duration of Unemployment, March 2000

42. Reto Schleiniger: Consumption Taxes and International Competitiveness in a Keynesian World, April 2000

43. Ernst Fehr and Peter K. Zych: Intertemporal Choice under Habit Formation, May 2000

44. Ernst Fehr and Lorenz Goette: Robustness and Real Consequences of Nominal Wage Rigidity, March 2003

45. Ernst Fehr and Jean-Robert Tyran: Does Money Illusion Matter? REVISED VERSION, May 2000

46. Klaus Reiner Schenk-Hoppé: Sample-Path Stability of Non-Stationary Dynamic Economic Systems, Juni 2000

47. Bruno S. Frey: A Utopia? Government without Territorial Monopoly, June 2000

48. Bruno S. Frey: The Rise and Fall of Festivals, June 2000

49. Bruno S. Frey and Reto Jegen: Motivation Crowding Theory: A Survey of Empirical Evidence, REVISED VERSION, June 2000

50. Albrecht Ritschl and Ulrich Woitek: Did Monetary Forces Cause the Great Depression? A Bayesian VAR Analysis for the U.S. Economy, July 2000

51. Alois Stutzer and Rafael Lalive: The Role of Social Work Norms in Job Searching and Subjective Well-Being, December 2000

52. Iris Bohnet, Bruno S. Frey and Steffen Huck: More Order with Less Law: On Contract Enforcement, Trust, and Crowding, July 2000

53. Armin Falk and Markus Knell: Choosing the Joneses: On the Endogeneity of Reference Groups, July 2000

54. Klaus Reiner Schenk-Hoppé: Economic Growth and Business Cycles: A Critical Comment on Detrending Time Series, May 2001 - Revised Version

55. Armin Falk, Ernst Fehr and Urs Fischbacher: Appropriating the Commons - A Theoretical Explanation, September 2000

56. Bruno S. Frey and Reiner Eichenberger: A Proposal for a Flexible Europe, August 2000

57. Reiner Eichenberger and Bruno S. Frey: Europe's Eminent Economists: A Quantitative Analysis, September 2000

58. Bruno S. Frey: Why Economists Disregard Economic Methodology, September 2000

59. Armin Falk, Ernst Fehr, Urs Fischbacher: Driving Forces of Informal Sanctions, May 2001

60. Rafael Lalive: Did we Overestimate the Value of Health?, October 2000

61. Matthias Benz, Marcel Kucher and Alois Stutzer: Are Stock Options the Managers' Blessing? Stock Option Compensation and Institutional Controls, April 2001

62. Simon Gächter and Armin Falk: Work motivation, institutions, and performance, October 2000

63. Armin Falk, Ernst Fehr and Urs Fischbacher: Testing Theories of Fairness - Intentions Matter, September 2000

64. Ernst Fehr and Klaus Schmidt: Endogenous Incomplete Contracts, November 2000

65. Klaus Reiner Schenk-Hoppé and Björn Schmalfuss: Random fixed points in a stochastic Solow growth model, November 2000

66. Leonard J. Mirman and Klaus Reiner Schenk-Hoppé: Financial Markets and Stochastic Growth, November 2000

67. Klaus Reiner Schenk-Hoppé: Random Dynamical Systems in Economics, December 2000

68. Albrecht Ritschl: Deficit Spending in the Nazi Recovery, 1933-1938: A Critical Reassessment, December 2000

69. Bruno S. Frey and Stephan Meier: Political Economists are Neither Selfish nor Indoctrinated, December 2000

70. Thorsten Hens and Beat Pilgrim: The Transfer Paradox and Sunspot Equilibria, January 2001

71. Thorsten Hens: An Extension of Mantel (1976) to Incomplete Markets, January 2001

72. Ernst Fehr, Alexander Klein and Klaus M. Schmidt: Fairness, Incentives and Contractual Incompleteness, February 2001

73. Reto Schleiniger: Energy Tax Reform with Excemptions for the Energy-Intensive Export Sector, February 2001

74. Thorsten Hens and Klaus Schenk-Hoppé: Evolution of Portfolio Rules in Incomplete Markets, October 2001

The Working Papers of the Institute for Empirical Research in Economics can be downloaded in PDF-format from http://www.unizh.ch/iew/wp/

Institute for Empirical Research in Economics, Blümlisalpstr. 10, 8006 Zürich, Switzerland

Phone: 004116343705 Fax: 004116344907 E-mail: bibiewzh@,iew.unizh.ch 


\section{Working Papers of the Institute for Empirical Research in Economics}

No.

75. Ernst Fehr and Klaus Schmidt: Theories of Fairness and Reciprocity - Evidence and Economic Applications, February 2001

76. Bruno S. Frey and Alois Stutzer: Beyond Bentham - Measuring Procedural Utility, April 2001

77. Reto Schleiniger: Global $\mathrm{CO}_{2}$-Trade and Local Externalities, April 2001

78. Reto Schleiniger and Stefan Felder: Fossile Energiepolitik jenseits von Kyoto, June 2001

79. Armin Falk: Homo Oeconomicus Versus Homo Reciprocans: Ansätze für ein Neues Wirtschaftspolitisches Leitbild?, July 2001

80. Bruno S. Frey and Alois Stutzer: What can Economists learn from Happiness Research?, October 2001

81. Matthias Benz and Alois Stutzer: Was erklärt die steigenden Managerlöhne? Ein Diskussionsbeitrag, June 2001

82. Peter A.G. VanBergeijk and Jan Marc Berk: The Lucas Critique in Practice: An Empirical Investigation of the Impact of European Monetary Integration on the Term Structure, July 2001

83. Igor V. Evstigneey, Thorsten Hens and Klaus Reiner Schenk-Hoppé: Market Selection of Financial Trading Strategies: Global Stability, July 2001

84. Ernst Fehr and Urs Fischbacher: Why Social Preferences Matter - The Impact of Non-Selfish Motives on Competition, Cooperation and Incentives, January 2002

85. Bruno S. Frey: Liliput oder Leviathan? Der Staat in der Globalisierten Wirtschaft, August 2001

86. Urs Fischbacher and Christian Thöni: Excess Entry in an Experimental Winner-Take-All Market, January 2002

87. Anke Gerber: Direct versus Intermediated Finance: An Old Question and a New Answer, September 2001

88. Klaus Reiner Schenk-Hoppé: Stochastic Tastes and Money in a Neo-Keynesian Econom, August 2001

89. Igor V. Evstigneev and Klaus Reiner Schenk-Hoppé: From Rags to Riches: On Constant Proportions Investment Strategies, August 2001

90. Ralf Becker, Urs Fischbacher and Thorsten Hens: Soft Landing of a Stock Market Bubble. An Experimental Study, January 2002

91. Rabah Amir, Igor V. Evstigneev, Thorsten Hens, Klaus Reiner Schenk-Hoppé: Market Selection and Survival of Investment Strategies, October 2001

92. Bruno S. Frey and Matthias Benz: Ökonomie und Psychologie: eine Übersicht, Oktober 2001

93. Reto Schleiniger: Money Illusion and the Double Dividend in the Short Run, October 2001

94. Bruno S. Frey: Flexible Citizenship for a Global Society, November 2001

95. Ernst Fehr and Armin Falk: Psychological Foundations of Incentives, November 2001

96. Takeshi Momi: Excess Demand Functions with Incomplete Markets - A Global Result, January 2002

97. Colin F. Camerer and Ernst Fehr: Measuring Social Norms and Preferences using Experimental Games: A Guide for Social Scientists, January 2002

98. Lars P. Feld and Bruno S. Frey: Trust Breeds Trust: How Taxpayers are Treated, January 2002

99. Aleksander Berentsen and Guillaume Rocheteau: Money and Information, January 2002

100.Aleksander Berentsen and Guillaume Rocheteau: Money and the Gains from Trade, January 2001

101. Aleksander Berentsen and Guillaume Rocheteau: On the Efficiency of Monetary Exchange: How Divisibility of Money Matters, January 2002

The Working Papers of the Institute for Empirical Research in Economics can be downloaded in PDF-format from http://www.unizh.ch/iew/wp/

Institute for Empirical Research in Economics, Blümlisalpstr. 10, 8006 Zürich, Switzerland

Phone: 004116343705 Fax: 004116344907 E-mail: bibiewzh@,iew.unizh.ch 